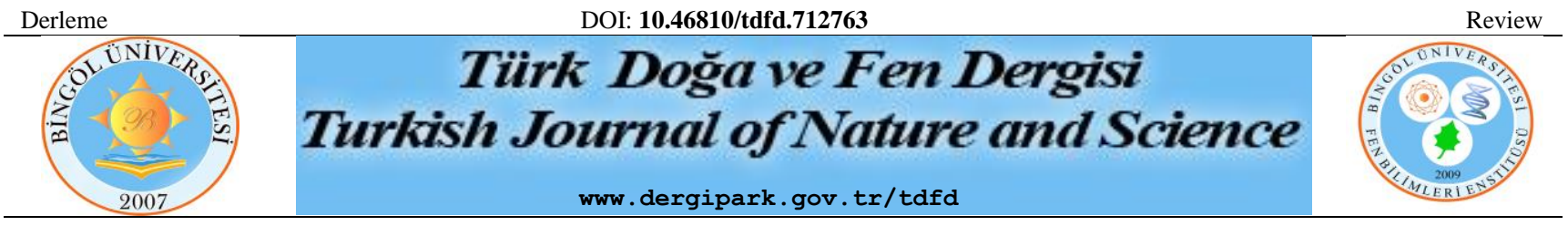

\title{
Ekolojik Risk Değerlendirmede Ekotoksikogenomik Kavramı ve Verdiği Katkılar
}

\author{
Mehmet Kürşat ŞAHIN ${ }^{1^{*}}$ \\ ${ }^{1}$ Karamanoğlu Mehmetbey Üniversitesi, Kamil Özdağ Fen Fakültesi, Biyoloji Bölümü, Karaman, Türkiye
} ORCID No: 0000-0003-0834-5081

*Sorumlu yazar: yasambilimci.kursat@gmail.com

(Alınış: 01.04.2020, Kabul: 04.06.2020, Online Yayınlanma: 18.06.2020)

\begin{abstract}
Anahtar Kelimeler
Ekotoksikogenomik, Toksikant,

Biyobelirteç,

Ekolojik risk

değerlendirilmesi
\end{abstract}

\begin{abstract}
Öz: Ekotoksikolojide, ekotoksikogenomik yaklaşımlar önemli bir alan olmaya başlamıştır. Toksikogenomikler önceleri kimyasalların insanlara risklerini belirlemek amacıyla kullanımdayken, bu konudaki son gelişmeler bu yaklaşımın diğer organizmalara da uygulanabilirliğini göstermiştir. Ekotoksikogenomik, ekosistemi temsil eden ve bireyler üzerinde olduğu kadar ekosistem üzerinde de kimyasalların zararlı etkilerinin çalışıldığı, organizmalara yönelik toksikogenomik bir uygulamadır. Ekotoksikogenomik belli bir toksikanta biyolojik sistemlerin bir yanıtı olarak, öncül gen ekspresyon çalışmalarından gelişmiştir. Zaman içinde olgunlaşan çalışmalar çeşitli -omik alanlarının toksikoloji ve patolojide kullanılmasına olanak sağlamıştır. Bu bağlamda ekolojik risk değerlendirme çalışmalarında çeşitli enzimler ve proteinlerin (örneğin Glutatyon S-transferaz, metallotiyonin, kolinesterazlar, $1 \mathrm{~s}$ - şok proteinleri) biyobelirteç olarak kullanılması canlılar üzerindeki potansiyel etkilerin gözlemlenmesine olanak sağlamıştır. Ayrıca birçok omurgalı ve omurgasız canlıda toksik etkiye maruz kalmanın belirlenmesinde mikroçip veya gen çiplerinden yararlanılarak hangi genlerin hücrede, dokuda, organda "up/down regüle" olarak ifade edilmesinin belirlenmesi de bu yaklaşımın bir diğer alanıdır. Etki ve genin sonuç özgü örüntüsü, protein ve metabolit profilleri, toksisitenin biyobelirteçleri olarak moleküler değişimleri tanımlamada kullanılmakta ve bu profiller, toksisite mekanizmalarını açıklamayı da sağlamaktadır. Bu yaklaşım ile çok sayıda farklı etkenin etki mekanizmalarını belirlenerek, belli tür ve populasyon alt gruplarında bu mekanizmaları yorumlayabilen genetik özellikleri gösterebilmektedir. Son yıllarda çevresel maruz kalma ile oluşan etkilerden korunma ya da etkinin azaltılmasında ekotoksikogenomik çalışmalar, multidisipliner kimliği ile hem erken uyarı değerlendirilmesini hem de maruz kalmanın ekosistemde oluşturduğu risklerin moleküler düzeyde etki mekanizmalarının açıklanmasını sağlayan bir bilim dalı olarak gelişmesini sürdürmektedir.
\end{abstract}

\section{Ecotoxicogenomics Concept and Its Contributions to Ecological Risk Assessment}

\author{
Keywords \\ Ecotoxicogenomic, \\ Toxicant, \\ Biomarker, \\ Ecological risk \\ assessment
}

\begin{abstract}
Ecotoxicogenomic approach has become an important area in ecotoxicology. While toxicogenomics were previously used to determine the risks of chemicals to humans, recent developments in this area have demonstrated that this approach is also applicable for other organisms.Ecotoxicogenomic is a toxicogenomic practice that represents the ecosystem and where harmful effects of chemicals are studied on the ecosystem as well as on individuals. Ecotoxicogenomics evolved from precursor gene expression studies as a response to a particular toxicant biological systems. Studies that have matured over time have allowed various -omic fields to be used in toxicology and pathology. In this context, the use of various enzymes and proteins (eg Glutathione S-transferase, metallothionine, cholinesterases, heatshock proteins) as biomarkers in ecological risk assessment studies has enabled the observation of potential effects on living things. In addition, determining which genes are expressed as "up / down regulated" in the cell, tissue and organ by using microarrays or gene chips in determining the exposure to toxic effects in many vertebrates and invertebrates. The result-specific pattern of effect and gene, protein and metabolite profiles are used to define molecular changes as biomarkers of toxicity, and these profiles also explain the mechanisms of
\end{abstract}


toxicity. With this approach, by determining the mechanisms of action of many different factors, it can show genetic features that can interpret these mechanisms in certain species and population subgroups. In recent years, ecotoxicogenomic studies continue to be developed as a branch of science that provides both early warning assessment and explanation of the mechanisms of action at the molecular level of the risks posed by the exposure in the ecosystem, with its multidisciplinary identity.

\section{TANIM}

Doğal ekosistemlerde çeşitli kimyasalların oluşturduğu etkileri inceleyerek, toksik maddelerin canlılar ve ekosistem üzerindeki etkilerini araştırıp, gösteren çalışmalar, bilindiği üzere “ekotoksikoloji”"nin özünü oluşturur. Ancak son zamanlarda modern genomik teknolojilerinin de klasik ekotoksikolojiye eklemlenmesi ile yeni bir çalışma alanı olarak "ekotoksikogenomik" alanı kendinden söz ettirmeye başlamıştır. Konuyu bu bağlamda ele alırken, göz ardı edilmemesi gereken temel hususlardan biri de sadece genomik verinin değil, proteomik, transkriptomik ve metabolomik verinin de bu konu içerisinde ele alındığı gerçeğidir [1]. Bununla birlikte ekotoksikogenomik alanında çalışmaların temelini ortaya çıkaran bu -omik yaklaşımının kökeninde "kimyasalların insanlara yönelik tehditlerini" ortaya çıkarmak olsa da, genetik alanındaki son gelişmeler bu alandaki bilgi donanımını diğer organizmalara da uygulanabilir kılmıştır. Böylelikle, ekotoksikogenomik kavramı "ekosistemi, verdiği yanıtlar bakımından temsil eden ve bu nedenle bireyler üzerinde olduğu kadar ekosistem üzerinde kimyasalların zararlı etkilerinin çalışıldığı toksikogenomik bir uygulama" olarak ifade edilebilir. Bu kapsamda araştırmacılar, çevresel stres etkenlerine veya toksikantlara genomun nasıl yanıt verdiği üzerinde çalışmalar yürütmüşlerdir [2-16].

\section{TARİHÇE}

Ekotoksikogenomik, belli bir toksikanta ya da referans ajanlarla kaplı etkenlere biyolojik sistemlerin bir yanıtı uygulama alanı olarak gören ve model organizmalardaki öncül gen ekspresyon çalışmalarından köken alarak zaman içinde gelişen bir bilim dalıdır (Tablo 1.). Maruz kalma ve genin sonuç özgü örüntülerini anlamada, protein ve metabolit profilleri ile toksisitenin biyobelirteçleri olarak moleküler değişimleri tanımlamada kullanılmıştır $[17,18]$. Ayrıca bu profiller, toksisite mekanizmalarını $[19,20]$ ve etki nedenlerini [21] kavramayı da sağlamıştır. Nuwaysir ve ark., [1999] "toksikogenomik" terimini, toksikolojik olarak ilgili genlerin yanıtlarını ölçerek ve seçici ve duyarlı biyobelirteçleri belirleyerek mikroçiplerin kullanımı ile tanımlamışlardır [2]. $\mathrm{Bu}$ anlamda mikroçip analizlerinden yararlanılarak çok sayıda kimyasal bileşik ile omik profillerinin ilişkisine yönelik bir çok çalıșma bulunmaktadır [22]. Maruz kalmadan sonra izole edilen RNA örneklerinin sitokin, kemokin ve matriks metalloproteinaz transkript profillerinde beklenilen yükselmeler gösterilmiştir. Benzer ekspresyon profilleri, yangısal hastalık sırasında meydana gelen biyolojik değişimleri taklit eden sistemlerde örneğin eklem hastalığ1 olan hastadaki sinoviyosit ve kondrositlerinde de görülmüștür.

Sonraki çalışmalar, diğer dokuların gözlemini ve toksikantların geniş yayılımını genişleterek, spesifik toksisite-moleküler profillerin çağrışımına imkan sağlamıştır. Bu kapsamda genom teknolojisi ile yapılan ilk çalışmalardan biri Kurşun bileşiklerinin bir sınıfı, Alzheimer hastalığında da sakıncalı etki olarak bulunan Notch1 tarafindan üretilen Hesl gen ürününün kırılma inhibisyonunun $\gamma$-sekretaz temelli bir keşif programı ile tanımlanmasıdır. Buradaki süreçte önemli olan nokta intestinal [barsak] epitel hücrelerindeki farklılıktır. Gen ekspresyon profilleme ve protein analiz sonuçlarının kullanımı ile, adipsin'i bu toksisite için bir biyobelirteç olarak tanımlamışlardır [23]. Açıkçası genomik temelli yaklaşımlar son teknolojiyi gereksindiğinden ötürü maliyetlidirler. İște bu sebeple, ekotoksikogenomik çalışmalara önemli bir katkı da özellikle ABD, Avrupa ülkeleri ve Uzakdoğu Asya'dan Japonya ve Güney Kore'deki büyük enstitüler ve konsorsiyumlar arası ișbirliği ile gelmiștir [24,25]. Bu sayede düzenleyici kuruluşlardan öne çıkan bilim insanları endüstriyel laboratuvarlarda, akademilerde ve idari organizasyonlarda, bir araya gelerek, bu çalışma alanındaki önemli noktaları tanımlayıp, buna dönük hedefleri işaret etmektedirler.

\subsection{Konsorsiyumlar}

Ekotoksikogenomik ile karşılaşılan problemler bilim insanlarının tek başlarına çözümleyebileceğinden daha geniş olup, veri toplanması ve karşılaştırılması doğrultusunda yaygın çabalara gereksinen, süratli gelişen durumlardır. 3 ana işbirlikçi araştırma konsorsiyumu, prensip olarak ölçümleri standardize edip, toksikogenomik deneylerin yorumuna rehber olmaları amacıyla oluşturulmuştur. $\mathrm{Bu}$ gruplardaki bilim insanlarının yönlendirmesiyle, endüstri bazlı idari ve akademik laboratuvarlar, birer düzenleyici kurumlar olarak, ilgili spesifik konuyu işaret eden araştırma enstitüleri ile organize halde çalışmalarını sürdürmektedir. Bu konsorsiyumlara örnek olarak ILSI (International Life Science Institute), EMBL (European Bioinformatics Institute), NIEHS (National Insitute of Environmental Health Services), Toxicogenomic Research Consortium -National Center for Toxicogenomics (NCT), Consortium for Metabonomics Technology (COMET), CREST Core Research for Evolutional Science and Technology gibi merkezler verilebilir. 
Tablo 1. Ekotoksikogenomik' in bilim tarihindeki yeri

\begin{tabular}{|c|c|c|}
\hline Tarih & Kirlilik kaynağı veya Bir bilim insanının atılımı & Etki veya yapılan çalışma \\
\hline 1850ler & Kömür yanma reaksiyon ürünleri & Güvelerde endüstriyel melanizm \\
\hline 1863 & Endüstriyel atık sular & İlk toksikoloji testleri \\
\hline 1866 & Mendel & Bezelyelerde kalıtım çalışmaları \\
\hline 1869 & Miescher & DNA yı saflaştıran ilk kişi \\
\hline 1874 & Kurşun atışları & Su kuşu ve sülün ölümleri \\
\hline 1887 & Maden yataklarından Argon emisyonu & Geyiklerde ve tilkilerde ölümler \\
\hline 1920 & Hans Winkler & Genom terimini ilk ortaya atan kişi \\
\hline 1927 & Petrol sahalarında hidrojen sülfitler & Memeli ve kuşlarda tükenmeler \\
\hline 1950ler & DDT ve organik klorlu pestisitler & Balık yiyen kuşların yumurta zarında incelmeler \\
\hline 1953 & Watson ve Crick & DNA'nın sarmal yapısının açıklanması \\
\hline 1960lar & Antikolin esteraz pestisidleri & Omurgalılarda tükenmeler \\
\hline 1970ler & Toksik atıkların karışımı & İnsan, sucul ve yaban hayatı sağlığına etkiler \\
\hline 1977 & Fred Sagner ve arkadaşları & Genomik çalışmalarını başlatmaları \\
\hline 1980ler & Tarımsal tahribatlar ve radyoaktif maddeler & Şekil bozuklukları ve üremede harabiyet \\
\hline 1990lar & Kompleks kimyasal karışımları [PCBler] & Endokrin bozucular \\
\hline 1991 & Pat Brown & DNA mikroarrayleri \\
\hline 2001-2003 & Celera Genomics & İnsan Genomu Projesi \\
\hline 2000ler & Çevresel strese neden olan ajanlar & Ekotoksikogenomik'in toksikolojinin bir kolu olarak yer almaya başlaması \\
\hline 2010 sonras1 & Toksik atıklar, kimyasallar & Ekotoksikogenomik ile uluslararası geçerli referans genlerin önerilmesi \\
\hline
\end{tabular}

\section{3. -OMIK'LER}

$\mathrm{Bu}$ başlık altında ifade edilen -omik kavramları toksisitenin hücreden ekosisteme giden hiyerarşik bir çerçeve içerisindeki fonksiyonları üzerinden değerlendirilmiştir (Şekil 1.).

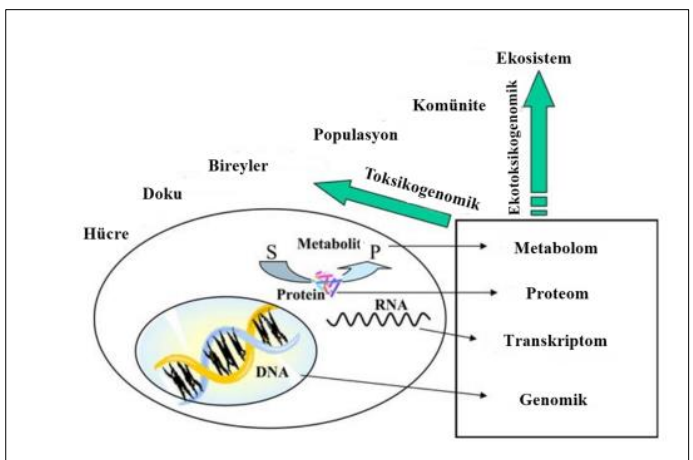

Şekil 1. hücreden ekosisteme -omik kavramlarının hiyerarşik katılımı [26]

\subsection{Türlerin Seçimi}

Ekotoksikolojik etkilerin çalışılmasında proteomik ve genomik uygulamalar için uygun tür seçimi çok önemlidir. Bundandır ki yapılacak analizin niteliğini temsil edebilecek türler önem kazanır. Örneğin denizkestanesi ve deniz üzümü gibi kimi durumlarda ayrıntılıca çalışılan bazı türler uygun adaylar olabilir. Çevresel toksikanta yanıtta karakteristik özellikler sergileyen Daphnia sp. (Su piresigiller) cinsinin türleri gibi gruplar önemli bilgiler sağlamaktadır. Dolayısıyla konu ele alınırken şayet bu çalışma ekotoksikogenomik bir çalışma olacak ise, aşağıdaki kriterleri sağlayan türler ekotoksikogenomik analizler için iyi modeller olarak düşünülebilir: bu türler kolay örneklenebilir olması ve laboratuvarda yetiştirilebilir olması. Böyle bir yaklaşım kimyasala maruz kalma çalışmalarında yarar sağlayan bir kontrol noktası olarak düşünülebilir. Zira bu aşamadan sonra laboratuvara adaptif bir tür seçimi, ekotoksikogenomik temelli bir çalışma için kritik bir diğer noktayı işaret eder. Çünkü, şayet maruz kalma şartları kontrol edilemez ise gen ekspresyon değişiminin nedenini aydınlatmak zordur. Organizmalar kontamine olmuş ve olmamış alanlardan örneklenmiş olsa bile, bazen kirleticilerin etkilerinin genetik nedenli mi yoksa diğerlerinden mi olduğunun farkında olmak zordur. Genom büyüklüğü de türlerin seçiminde bir diğer kritik faktördür. Bununla birlikte, zaman ve genomik sekanslamanın maliyeti direk olarak genom büyüklüğüne bağlı olup; türler arasında değişkenlik gösterebilmektedir.

Aşağıdaki tabloda çeşitli türlerde kirleticilere ilişkin genomik yaklaşım çalışmaları sunulmuştur (Tablo 2). 
Tablo 2. Farklı türlerde kirleticilerle ilişsin genomik yaklaşım çalışmaları [26]

\begin{tabular}{|c|c|c|c|}
\hline Kirletici & Organizma & Genomik yaklaşım & Referans \\
\hline \multicolumn{4}{|l|}{ Pestisitler } \\
\hline Klorpirifos, Diazinon & Rattus norvegicus & 252 Gen bölgesi & Slotkin ve Seidler, 2007 \\
\hline Diazinon & Homo sapiens & 600 Gen bölgesi & Mankame ve ark., 2006a,b \\
\hline Diazinon & Oryzias latipes & Diferansiyel görünüm & Yoo ve ark., 2007 \\
\hline Fenarimol & Daphnia magna & SSH PZR, cDNA bölgesi & Soetaert ve ark., 2007 \\
\hline Mianserin & Danio rerio & Beyin spesifik & van der Ven ve ark., 2006b \\
\hline \multicolumn{4}{|l|}{$\begin{array}{l}\text { Yeni ortaya çıkan } \\
\text { kirleticiler }\end{array}$} \\
\hline 2,4- 2,4-Dinitrotoluen & $\begin{array}{l}\text { Pimephelas } \\
\text { promelas }\end{array}$ & cDNA bölgesi & Wintz ve ark., 2006 \\
\hline $\begin{array}{l}\text { Bis [Tri- } N \text {-bütilin] oksit } \\
\text { [TBTO] }\end{array}$ & Rattus norvegicus & Oligo bölgesi & Baken ve ark., 2007 \\
\hline Bromobenzen & Rattus norvegicus & Afimetrik bölgeler & Tanaka ve ark., 2007a \\
\hline Bromobenzen & Rattus norvegicus & $\begin{array}{l}\text { Metabolomik/gen } \\
\text { ekspresyonu }\end{array}$ & Hejine ve ark., 2005 \\
\hline Nanopartiküller [C50] & Danio rerio & Afimetrik bölgeler & Henry ve ark., 2007 \\
\hline Perklorat & Xenopus laevis & cDNA bölgesi, Q-PZR & Helbing ve ark., 2007 \\
\hline $\begin{array}{l}\text { Perflorooktanoik asit } \\
\text { [PFOA] }\end{array}$ & Rattus norvegicus & Afimetrik bölgeler & Guruge ve ark., 2006 \\
\hline PFOA & Gobiocyrpis rarus & cDNA bölgesi, Q-PZR & Wei ve ark., 2008 \\
\hline PFOA & Mus musculus & Afimetrik bölgeler & Rosen ve ark. 2007 \\
\hline $\begin{array}{l}\text { PFOA, perflorooktan } \\
\text { sulfonat asit [PFOS] }\end{array}$ & Gallus gallus & Genom bölgeleri & Yeung ve ark., 2007 \\
\hline $\begin{array}{l}\text { RDX (siklotrimetilen- } \\
\text { trinitramin) }\end{array}$ & $\begin{array}{l}\text { Populus } \quad \text { nigra } \\
\text { DN34 }\end{array}$ & RT-PZR & Tanaka ve ark., 2007b \\
\hline RDX & Rattus norvegicus & Oligo bölgesi & Perkins ve ark., 2006 \\
\hline RDX & $\begin{array}{l}\text { Arabidopsis } \\
\text { thaliana }\end{array}$ & SAGE & Ekman ve ark., 2005 \\
\hline Tribütilin & Salmo salar & RT-PZR & Mortensen ve Arukwe, 2007 \\
\hline Tribütilin & $\begin{array}{l}\text { Tetrahymena } \\
\text { thermophila }\end{array}$ & SSH, Q-PZR & Feng ve ark., 2007 \\
\hline Trimetilbenzen & Rattus norvegicus & Mikroçip & McDougal ve Garrett, 2007 \\
\hline Vanadium & Rattus norvegicus & Afimetrik bölgeler & Willsky ve ark., 2006 \\
\hline \multicolumn{4}{|l|}{ Farmasötikler } \\
\hline Klorpromazin & Danio rerio & Beyin spesifik bölgeler & van der Ven ve ark., 2005 \\
\hline $\begin{array}{l}13 \\
\text { karışımı farmasötiğin }\end{array}$ & Danio rerio & Oligo bölgesi & Pomati ve ark., 2007 \\
\hline Propikonazol & Daphnia magna & cDNA bölgesi & Soetaert ve ark., 2006 \\
\hline
\end{tabular}




\begin{tabular}{|c|c|c|c|}
\hline Kirletici & Organizma & Genomik yaklaşım & Referans \\
\hline \multicolumn{4}{|l|}{ Kompleks karışımlar } \\
\hline Atık sular & Cyprinus carpio & cDNA mikroçipi & Moens ve ark. 2007a \\
\hline Herbisit karışımı & Platichthys flesus & $\mathrm{SSH}$ & Marchand ve ark. 2006 \\
\hline Çoklu kirleticiler & $\begin{array}{l}\text { Phalacrocorax } \\
\text { carbo }\end{array}$ & cDNA mikroçipi & Nakayama ve ark., 2006 \\
\hline $\begin{array}{l}\text { Kağıt fabrikası atık } \\
\text { suyu }\end{array}$ & $\begin{array}{l}\text { Micropterus } \\
\text { salmoides }\end{array}$ & Diferansiyel görünüm & Denslow ve ark., 2004 \\
\hline \multicolumn{4}{|l|}{ Endokrin bozucular } \\
\hline $\begin{array}{l}\text { 17 } \alpha \text {-etinilöstradiol } \\
\text { [EE2] }\end{array}$ & Danio rerio & Oligo bölgesi & Santos ve ark., 2007 \\
\hline EE2 & Danio rerio & Oligo bölgesi, RT-PZR & Martyniuk ve ark., 2007 \\
\hline EE2 & Carassius auratus & cDNA mikroçipi & Martyniuk ve ark., 2006 \\
\hline EE2 & $\begin{array}{l}\text { Oncorhynchus } \\
\text { mykiss }\end{array}$ & cDNA mikroçipi & Hook ve ark., 2006 \\
\hline $\begin{array}{l}17 \beta \quad \text { östradiol, } \\
\text { nonilfenol[4NP], } \\
\text { dikoro-2,2-bis } 1,1- \\
\text { klorofenil] etilen }\left[\mathrm{P}, \mathrm{P}^{\prime}-\right. \\
\begin{array}{l}\mathrm{DDE}] \\
\end{array}\end{array}$ & $\begin{array}{l}\text { Micropterus } \\
\text { salmoides }\end{array}$ & Makroçip & Larkin ve ark., 2003 \\
\hline $17 \beta$ östradiol & $\begin{array}{l}\text { Pimephelas } \\
\text { promelas }\end{array}$ & Oligo bölgesi & Larkin ve ark., 2007 \\
\hline 4NP (4-nonilfenol) & Oryzias latipes & Oligo bölgesi & Kim ve ark. 2006 \\
\hline 4NP, bisfenol A, EE2 & Cyprinus carpio & cDNA mikroçipi & Moens ve ark., 2007b \\
\hline Fadrozol & $\begin{array}{l}\text { Pimephelas } \\
\text { promelas }\end{array}$ & Oligo bölgesi & Villeneuve ve ark., 2007 \\
\hline Flutamid, EE2 & $\begin{array}{l}\text { Pimephelas } \\
\text { promelas }\end{array}$ & Q-PZR & Filby ve ark., 2007 \\
\hline $\begin{array}{l}\text { Progesteron, Östrojen, } \\
\text { Testosteron }\end{array}$ & $\begin{array}{l}\text { Caenorhabditis } \\
\text { elegans }\end{array}$ & cDNA mikroçipi & Custodia ve ark., 2001 \\
\hline
\end{tabular}

\subsection{Omurgalılarda ve Omurgasızlarda Endokrin Bozucuların Ekotoksikogenomik Uygulamaları}

Poliklorlu bifeniller, dioksin ve çevresel endokrin bozucu kimyasallar ve plastikleștirici, farmasötikler gibi pestisidler ve doğal hormonlar steroid ve retinoid reseptörlerle etkileşmektedir [27-30]. Bu kimyasallar genellikle östrojenik aktivite gösterir ve yapısal olarak fenol halkasına benzer oldukları söylenebilir [31]. Reseptör bazlı işlevsel deneyler, çeşitli çevresel kimyasalların kabul edilen biyolojik aktivitelerini tespit etmede kullanılmıştır [32]. Bu östrojenik kimyasallara nonilfenol [NP], bisfenol A [BPA], östron ve $17 \beta$ östradiol [E2] verilebilir [33]. Bu bağlamda ülkemizde de yaygın olarak kullanılan model organizma olan farelerde endokrin bozucuların etkileri üzerine yapılan çalışmalar şöyle sunulabilir:

\section{Fare}

cDNA mikroçip metodu, hormonlar tarafindan düzenlenen gen ekspresyon analizlerinin genom çapında başarılı uygulamaları yıldan yıla gelişmekte olan bir yaklaşımdır [34-37]. Östrojen yanıt genlerinin ekspresyonundaki örüntülerin bilgisi, farelerin üreme organları üzerinde östrojenik kimyasalların etki mekanizmasını anlamak için gereklidir. Seçilen çok sayıda gen için; ekspresyon, doz bağımlı tarzda indüklenir. Karakteristik gen ekspresyon örüntüleri her çevresel östrojenik kimyasal için gözlenmiş ve bu örüntülerin E2'den farkl1 oldukları, böylece endojenik östrojence indüklenmeden farklı olan spesifik etki mekanizmaları olabileceği önerilmiştir [38].

Fizyolojik östrojenler E2, fizyolojik olmayan östrojenler [DES] ve dioksinlerin uterus gen ekspresyonu üzerinde farklı etkiler gösterdiği söylenmiştir [39]. Karaciğerde, bununla birlikte östrojenik yanıt genlerinden farklı olarak NP ve dioksinin farklı gen setlerini aktive ettiği bulunmuştur [38-40]. Böylece ancak küçük bir miktar genin direk olarak östrojen uygulanması ile uterotrofik etkilerinin olduğu, uterustaki gen ekspresyonunda da E2'nin NP'ye benzer etkileri olduğu ancak hepatik doku için durumun böyle olmadığı rapor edilmiştir.

Genel olarak bakıldığında, bu tip bir konuyu ekotoksikoproteomik prensiplere uygun yönlendirmek 
gerekirse de tür seçimi için benimsenecek genomik yaklaşıma göre farklılık sağlayabilecek başlıca kriterler ise şunlardır: hedef tür yine kolay örneklenebilir olmalı fakat bu türün toksikanta yanıtı akut ölüm yada ölümcül dozda toksikanta maruz kalma değil, uzun dönemli protein ekspresyonunda meydana gelebilen bozukluklar ele alınmalıdır. Bunun yanı sıra yaşamsal faaliyetlerde rol alması nedeniyle evrensel olarak düşünülen sitokrom P450, kolinesteraz, katalaz, glutatyon S-transferaz, vitellogen, 1sı şok proteinleri gibi başlıca biyobelirteçleri kullanmak ekosistem analizleri için de fayda sağlayacaktır [41-43] (Tablo 3).

Tablo 3. Moleküller profiller kullanılarak, farklı canlılarda yapılan çalıșmaların değerlendirilmesi [44]

\begin{tabular}{|c|c|c|c|c|c|}
\hline $\begin{array}{l}\text { Sinanan } \\
\text { koșullar }\end{array}$ & Organizma & $\begin{array}{l}\text { Tanımlanmış hücresel etkisi } \\
\text { gözlenmiş işlem }\end{array}$ & Sinanan dokular & $\begin{array}{l}\text { Organizasyon } \\
\text { düzeyi }\end{array}$ & Referanslar \\
\hline \multirow[t]{4}{*}{$\begin{array}{l}\text { Östrojen } \\
\text { Ksenoöstrojen }\end{array}$} & Salmonidler & $\begin{array}{l}\text { Östrojen sinyalizasyonu, } \\
\text { transkripsiyon } \\
\text { detoksifikasyon, stres }\end{array}$ & Beyin, karaciğer & Transkript & $\begin{array}{l}\text { Gallagher ve ark.[2008], } \\
\text { Meucci ve Arukwe[2006], } \\
\text { Mortensen } \\
\text { Arukwe[2007a,b], ve Veldhoen } \\
\text { ve ark. [2010] }\end{array}$ \\
\hline & Diğer teleostlar & $\begin{array}{l}\text { Hücre proliferasyonu, protein } \\
\text { sentezi, taşınım ve immüno } \\
\text { yanıtlar }\end{array}$ & Karaciğer & Transkript & Williams ve ark.[2007] \\
\hline & Yumuşakçalar & $\begin{array}{l}\text { Detoksifikasyon, } \\
\text { oksiradikalmetabolizma, } \\
\text { hormon regülasyonu, enerji } \\
\text { metabolizması,immune } \\
\text { işlevler }\end{array}$ & $\begin{array}{l}\text { Sindirim bezi, } \\
\text { hemolenf plazma }\end{array}$ & Protein & $\begin{array}{l}\text { Amelina ve ark,.[2007], Apraiz } \\
\text { ve ark, [2006], Bjornstad ve } \\
\text { ark,2006], Knigge ve ark, } \\
{[2004], \text { Mi ve ark, [2007], ve }} \\
\text { Zhou ve ark,.[2010] }\end{array}$ \\
\hline & Deniz kestanesi & Hormon düzenlenmesi & Yumurta & Transkript & Roepke ve ark.,2006] \\
\hline $\begin{array}{l}\text { Üreme } \\
\text { olgunluğu, göç-- } \\
\text { smoltifikasyon ya } \\
\text { da yumurtlama }\end{array}$ & Salmonidler & $\begin{array}{l}\text { Östrojen düzenlenmesi, } \\
\text { transkripsiyon kontrolü, } \\
\text { detoksifikasyon ve stres }\end{array}$ & Beyin ve karaciğer & Transkript & $\begin{array}{l}\text { Gallagher ve ark.,[2008], Meucci } \\
\text { ve Arukwe[2006], Mortensen ve } \\
\text { Arukwe[2007a,b], ve Veldhoen } \\
\text { ve ark.,[2010] }\end{array}$ \\
\hline $\begin{array}{lr}\text { Farklı } & \text { larval } \\
\text { evreler } & \text { ve } \\
\text { erginlik } & \end{array}$ & Diğer teleostlar & Çeşitli & Çeşitli & Transkript & Douglas ve ark.,[2007] \\
\hline $\begin{array}{l}\text { Eşey } \\
\text { belirlenmesi }\end{array}$ & Yumuşakçalar & $\begin{array}{l}\text { Aminoasit / protein } \\
\text { metabolizması }\end{array}$ & Manto & Metabolit & Hines ve ark., [2007] \\
\hline \multirow[t]{4}{*}{$\begin{array}{l}\text { Poliaromatik } \\
\text { kirleticiler }\end{array}$} & Salmonidler & Detoksifikasyon ve stres & Karaciğer & Transkript & $\begin{array}{l}\text { Mortensen ve Arukwe[2007a], } \\
\text { Rees ve Li [2004], Rees ve } \\
\text { ark.,[2005], ve Rees ve } \\
\text { ark.,[2003] }\end{array}$ \\
\hline & Salmonidler & Enerji metabolizması & Karaciğer ve Kas & Metabolit & $\begin{array}{l}\text { Lin ve ark. [2009], Tjeerdema } \\
\text { [2008], van Scoy ve ark. [2010] } \\
\text { ve Viant ve ark. [2006] }\end{array}$ \\
\hline & Yüzgeçayaklılar & $\begin{array}{l}\text { Hormon düzenlenmesi, enerji } \\
\text { metabolizmasi, } \\
\text { detoksifikasyon }\end{array}$ & $\begin{array}{l}\text { Karaciğer, Kan, } \\
\text { deri/yağ }\end{array}$ & $\begin{array}{l}\text { Transkript, } \\
\text { Protein ve } \\
\text { Metabolit }\end{array}$ & $\begin{array}{l}\text { Brouwer ve ark.[1998], Cole ve } \\
\text { ark. [2009], Hammond ve ark. } \\
\text { [2005], Hirakawa ve ark.2007], } \\
\text { Kim ve ark. [2005], Mos ve } \\
\text { ark. [2007], Tabuchi ve ark. } \\
\text { [2006], Rolland [2000], ve } \\
\text { Sormo ve ark. [2005] }\end{array}$ \\
\hline & Yumuşakçalar & $\begin{array}{lr}\text { Detoksifikasyon, } & \text { oksiradikal } \\
\text { metabolizma, } & \text { hormone } \\
\text { regülasyonu, } & \text { enerji } \\
\text { metabolizması, immun işlevler }\end{array}$ & $\begin{array}{l}\text { Sindirim bezi, } \\
\text { hemolenf plazma }\end{array}$ & Protein & $\begin{array}{l}\text { Amelina ve ark.[2007], Apraiz } \\
\text { ve ark.[2006], } \\
\text { Bjornstad ve ark.[2006], } \\
\text { Knigge ve ark. [2004], Mi ve } \\
\text { ark.[2007], ve Zhou ve ark } \\
{[2010]}\end{array}$ \\
\hline $\begin{array}{l}\text { Ağır metaller, } \\
\text { bakteriyel } \\
\text { enfeksiyonlar, } \\
\text { kişisel bakım } \\
\text { ürünleri, } \\
\text { pestisidler, } \\
\text { poliaromatik } \\
\text { kirleticier }\end{array}$ & Yumuşakçalar & $\begin{array}{l}\text { Detoksifikasyon, immun } \\
\text { işlevler, stress, transkripsiyon } \\
\text { kontrolü }\end{array}$ & Çeşitli & Transkript & $\begin{array}{l}\text { Cellura ve ark.,2007], Dondero } \\
\text { ve ark., [2006b], Feldstein ve } \\
\text { ark., [2006],Franzellitti ve } \\
\text { Fabbri [2005], Franzellitti ve } \\
\text { Fabbri[2006], La Porte [2005], } \\
\text { Luckenbach ve Epel[2005], } \\
\text { Song ve ark.,[2006], Tanguy ve } \\
\text { ark.[2005], ve Venier ve ark., } \\
\text { [2006] }\end{array}$ \\
\hline
\end{tabular}




\begin{tabular}{|c|c|c|c|c|c|}
\hline $\begin{array}{l}\text { Sinanan } \\
\text { koşullar }\end{array}$ & Organizma & $\begin{array}{l}\text { Tanımlanmış hücresel etkisi } \\
\text { gözlenmiş işlem }\end{array}$ & Sinanan dokular & $\begin{array}{l}\text { Organizasyon } \\
\text { düzeyi }\end{array}$ & Referanslar \\
\hline $\begin{array}{l}\text { Yakalama I } \\
\text { Kirletici baskısı }\end{array}$ & $\begin{array}{l}\text { Salmonidler, } \\
\text { Yüzgeç } \\
\text { ayaklıllar }\end{array}$ & $\begin{array}{l}\text { İmmün yanıtlar, Stres, İmmün } \\
\text { işlevleri, Enerji metabolizması }\end{array}$ & $\begin{array}{lr}\text { Karaciğer, } & \text { Deri, } \\
\text { Periferal } & \text { kan } \\
\text { lökositleri } & \end{array}$ & $\begin{array}{l}\text { Protein, } \\
\text { Transkript }\end{array}$ & $\begin{array}{l}\text { Ellis ve ark.[2009], Mancia ve } \\
\text { ark.[2007] ve Mancia ve ark. } \\
\text { [2008] }\end{array}$ \\
\hline \multirow[t]{7}{*}{$\begin{array}{l}\text { Viral ya da } \\
\text { bakteriyal } \\
\text { enfeksiyon }\end{array}$} & Salmonidler & İmmün yanıt & $\begin{array}{l}\text { Makrofaj, } \\
\text { hematopoietik } \\
\text { böbrek }\end{array}$ & Transkript & Rise ve ark. [2004a] \\
\hline & Salmonidler & İmmün yanıt & Karaciğer & Protein & $\begin{array}{l}\text { Booy ve ark. [2005] ve Provan } \\
\text { ve ark. [2006] }\end{array}$ \\
\hline & Diğer teleostlar & İmmün yanıt & Dalak & Transkript & Rise ve ark. [2008] \\
\hline & Deniz kestanesi & $\begin{array}{l}\text { RNAsplaysing, protein işleme } \\
\text { ve hedefleme, sekresyon, } \\
\text { endozomal aktivitiler,hücre } \\
\text { düzenlenmesi, hücre iskelet } \\
\text { yapisı }\end{array}$ & Sölomositler & Transkript & Nair ve ark [2005] \\
\hline & Deniz kestanesi & İmmün yanıt & Sölmositler & Protein & Dhelly ve ark [2011] \\
\hline & Karides & $\begin{array}{l}\text { Antimikrobiyal faaliyetler, } \\
\text { oksidatif stres }\end{array}$ & Hepatopankreas & Transkript & Robalino ve ark. [2007] \\
\hline & Karides & $\begin{array}{l}\text { İmmün yanıt, oksidatif stres, } \\
\text { Deri değiştirme proteinleri, } \\
\text { stres }\end{array}$ & Hepatopankreas & Protein & Chai ve ark [2010] \\
\hline $\begin{array}{l}\text { Bakteriyal } \\
\text { enfeksiyon, } \\
\text { besin } \\
\text { sinırlandırma ve } \\
\text { sicaklik stresi }\end{array}$ & Yumuşakçalar & $\begin{array}{l}\text { Osmoregülasyon, } \\
\text { aminoasit/protein/nükleotit } \\
\text { metabolizmas1, karbonhidrat } \\
\text { ve enerji metabolizması }\end{array}$ & $\begin{array}{l}\text { Yaklaştırıcı kas, } \\
\text { sindirim bezi }\end{array}$ & Metabolit & Rosenblum ve ark [2005] \\
\hline \multirow[t]{3}{*}{$\begin{array}{l}\text { Populasyon } \\
\text { adaptasyonu }\end{array}$} & Diğer teleostlar & $\begin{array}{l}\text { Hücre yönlendirme ve enerji } \\
\text { metabolizmas }\end{array}$ & Beyin & Protein & Gonzales ve ark. [2010] \\
\hline & Diğer teleostlar & Protein metabolizması & Karaciğer & Protein & Gonzales ve ark. [2010] \\
\hline & Diğer teleostlar & $\begin{array}{l}\text { Demir/Hem biyosentezi, } \\
\text { osmoregülasyon }\end{array}$ & Karaciğer & Transkript & Larsen ve ark. [2007] \\
\hline $\begin{array}{l}\text { Hipoksi, soğuk } \\
\text { ve sicak stresi }\end{array}$ & Diğer teleostlar & 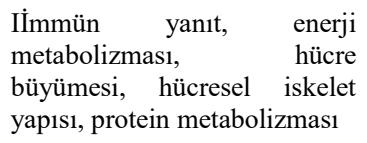 & Karaciğer & Transkript & Kassahn ve ark. [2007] \\
\hline Hipoksi & Karides & $\begin{array}{l}\text { Oksidatif stres, stress, } \\
\text { mitokondrial işlevler, yağ } \\
\text { taşınımı, protein sentezi, enerji } \\
\text { metabolizması }\end{array}$ & $\begin{array}{l}\text { Hepatopankreas } \\
\text { ve hemosit }\end{array}$ & Transkript & $\begin{array}{l}\text { Brown-Peterson ve ark2008] ve } \\
\text { de laVega ve ark. [2007a,b] }\end{array}$ \\
\hline Osmotik stres & Karides & $\begin{array}{l}\text { Protein metabolizması, } \\
\text { Hücresel iskelet yapısı, enerji } \\
\text { metabolizması, immun işlevler }\end{array}$ & Hemositler & Transkript & de la Vega ve ark. [2007a,b] \\
\hline Is1 stresi & Karides & $\begin{array}{l}\text { Protein metabolizması, } \\
\text { Hücresel iskelet yapısı, enerji } \\
\text { metabolizması, mmune } \\
\text { işlevler }\end{array}$ & Hemositler & Transkript & de la Vega ve ark. [2007a,b] \\
\hline \multirow[t]{3}{*}{$\begin{array}{l}\text { Metaller/ Ağır } \\
\text { metaller }\end{array}$} & Diğer teleostlar & $\begin{array}{l}\text { Detoksifikasyon, enerji } \\
\text { metabolizmas1, protein demeti, } \\
\text { mitokondriyal solunum, }\end{array}$ & Karaciğer & Transkript & Sheader ve ark. [2006] \\
\hline & Diğer telesotlar & $\begin{array}{l}\text { Enerji metabolizması, sinyal } \\
\text { geçişi, stres }\end{array}$ & Beyin & Protein & Keyvanshokooh ve ark. [2009] \\
\hline & Deniz kestanesi & Detoksifikasyın & Embriyo & Transkript & $\begin{array}{l}\text { Cserjesi ve ark.[1997] ve } \\
\text { Scudiero ve ark.[1997] }\end{array}$ \\
\hline
\end{tabular}




\begin{tabular}{|c|c|c|c|c|c|}
\hline $\begin{array}{l}\text { Sinanan } \\
\text { koşullar }\end{array}$ & Organizma & $\begin{array}{l}\text { Tanımlanmış hücresel etkisi } \\
\text { gözlenmiş işlem }\end{array}$ & Sinanan dokular & $\begin{array}{l}\text { Organizasyon } \\
\text { düzeyi }\end{array}$ & Referanslar \\
\hline \multirow[t]{3}{*}{ Pestisitler } & Diğer teleostlar & Oksidatif stres & Karaciğer & Protein & Chen ve Huang[2011] \\
\hline & Deniz kestanesi & Proteoliz, transkripsiyon & Embriyo & Transkript & Marc ve ark [2005] \\
\hline & Yumuşakçalar & $\begin{array}{lr}\text { Aminoasit } & \text { protein } \\
\text { metabolizmas1, } & \text { azot } \\
\text { metabolizmasi } & \end{array}$ & $\begin{array}{l}\text { Manto, } \\
\text { yaklaştırıcı kas }\end{array}$ & Metabolit & Hines ve ark. [2010] \\
\hline \multirow[t]{3}{*}{$\begin{array}{l}\text { Kirlilik } \\
\text { düzeyleri }\end{array}$} & Diğer teleostlar & $\begin{array}{l}\text { Hormon düzenlenmesi, } \\
\text { detoksifikasyon }\end{array}$ & Karaciğer & Transkript & Baker ve ark [2009] \\
\hline & Yumuşakçalar & $\begin{array}{l}\text { Stres, kolaylaştırılmış } \\
\text { membran transportu }\end{array}$ & $\begin{array}{l}\text { Yaklaştırıci kas, } \\
\text { gonad ve } \\
\text { hepatopankreas }\end{array}$ & Transkript & $\begin{array}{l}\text { Veldhoen ve ark [2011] ve } \\
\text { Veldhoen ve ark [2009] }\end{array}$ \\
\hline & Yumuşakçalar & $\begin{array}{lr}\text { Detoksifikasyon, } & \text { protein } \\
\text { metabolizmas1, } & \text { enerji } \\
\text { metabolizmas1, stres } & \end{array}$ & Sindirim bezi & Protein & $\begin{array}{l}\text { Amelina ve ark [2007], Knigge } \\
\text { ve ark [2004] ve Mi ve ark } \\
\text { [2005] }\end{array}$ \\
\hline
\end{tabular}

* smoltifikasyon: juvenil salmonidlerin tuzlu su ile başa çıkabilmesi için geçirdiği fizyolojik değişimlerin süreci

$\mathrm{Bu}$-omik profilleri üzerine çevresel etkenlerin yansıması, çoklu değişken veri analizleri ile beraber hücresel düzeyde gözlenen bir etkinin domino etkisi biçiminde tüm ekosistemi de tehdit edebileceği söylenilmektedir. Örneğin Birleşmiş Milletlerin yayınladığ 1 bir çevre raporunda Nijerya'daki Nijer deltası başta hidrokarbonların degredasyonu olmak üzere metan gazı ve karbon IV oksit gibi yağ türevlerinin oluşturduğu kirlilik ile karşı karşıyadır [44]. Söz konusu alanda brnzen ve polisiklik aromatik hidrokarbon (PAH) değerleri de Dünya Sağlık Örgütü’nün öngördüğü üst sinırlardan sirasıyla 1800 ve 500 kat daha yüksektir [44]. Burada metagenomik bazlı yürütülen bir çaşışmada Udofia ve ark, (2018) özellikle petrol bazlı hidrokarbon biyodegredasyon enzim yetkinlikleri olan mikroorganizmalar kullanılarak (örneğin Pseudomonas stutzeri ve Acidovorax sp.), kirlilik seviyesinin azaltılmasında başarı sağlanmıştır [44].

\section{AMAÇ ve ARAÇLAR}

Ekotoksikogenomiğin, 3 temel hedefi vardır:

i. Çevresel maruz kalma ve organizmadaki etken duyarlılığı arasındaki iliş̧kileri anlama,

ii. Etkenin ve toksik maddelere maruz kalmanın faydalı biyobelirteçlerini tanımlama ve

iii. Toksisitenin moleküler mekanizmalarını aydınlatma.

\section{1. Örnek Bir Modelleme}

Tipik bir toksikogenomik deneyinde, her biyolojik örnek için kayda değer farklılıkta ifade edilen genlerin listeleri oluşturulur. Alternatif olarak ise, genleri ve ilginin gen profilini tanımlamak için profil - analiz metotları doz ilişkili ya da süreç çalışmaları olarak uygulanabilir. Sonra, literatür taramaları, karşılaştırma analizleri ve moleküler ekspresyon veri setlerinin tekrarlamalı biyolojik modelleri üzerinden sistematik olarak çıkarılan ve toplanılan ilgili bilginin yardımıyla; bu değişimlerden (ya da biyobelirteçler) gelen benzer kliniksel ya da görülen yan etkileriyle, ilgili biyolojik sistemlerin adaptif yanıtlarını ayrıştırmak mümkün olur. Geçen on yılda, ekotoksikogenomik yaklaşımı; gen ekspresyon profillerinin konseptini, toksikant sinıflarının, etken alt tiplerininin veya diğer biyolojik son noktalarının [endpoint] bir "imzası" olarak onaylamıştır [45]. Bu imzalar, toksikant etkilerinin tahmin edici biyobelirteçlerinin analitik araştırmalarında etkili olarak yönlendirdiği gibi, aynı zamanda toksik ve adaptif yanıtlar arasındaki bağlantılı moleküler mekanizmalarda dinamik ayrışmanın anlaşılmasına da katkı sağlamıştır.

Toksikogenomik çalışmayı ve gen ekspresyon verilerinin üretildiği toplamı içeren bir deneysel çalışma çok büyüktür. Hatta inceleme yapmak, her bir doz - zaman grubunda, her bir hayvan başına bir doku için $18-45$ mikroçip (eğer replikantlar kullanılacak ise daha fazla) ve çip başına 20000 ya da daha fazla transkriptin ilgili ölçümlerine gereksinir. Ayrıca, hayvan başına tipik uygulama ilgili veriler (vücut ağırlı̆̆ı, organ -ağırlık ölçümleri, klinik kimyasal ölçümler, çeşitli dokular için mikroskobik histopatolojik bulgular gibi) de hesaba katılmalıdır. Bu verilerin dikkatli toplanması, yönetimi ve entegrasyonu, deney protokolünün içeriğinde olup, toksikolojik sonuçlar için yorumlanması için zorunludur.

Böylece, dozla, zamanla ve önemli toksikolojik ve/veya histopatolojik fenotip(ler) yönünden olan bütün veriler kaydedilmelidir. Bu tip deneysel verilerin derlenmesi, sayisal modelleme ve toksikoinformatikle beraber, toksikant ilgili etkenleri yeniden anlamanın sağlanmasıyla önem arz edecektir. Aşağıdaki çerçevede toksikogenomiğin, geleneksel toksikolojik ve histopatolojik bulgularının son noktalarından hesaplanıp, -omiklerce derlenen bir entegrasyon şemas1 görülmektedir (Şekil 2). Bu entegrasyon, toksikolojik sonuçlar ve moleküler genetik arasındaki ilişkiyi sinerjistik biçimde anlamamızı sağlayan bir potansiyel sahiptir. 


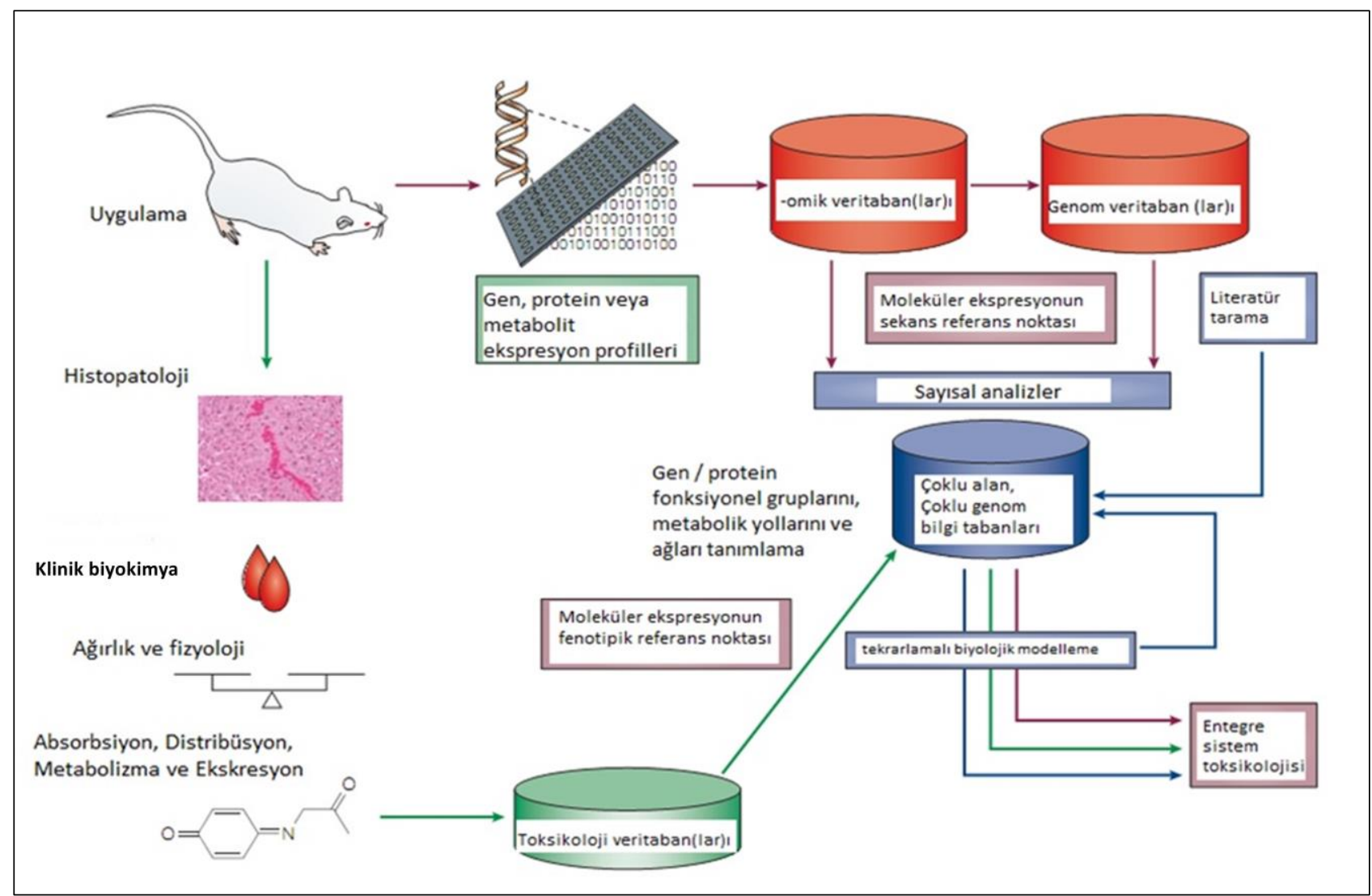

Şekil 2. Sistem toksikoloji çalışma çerçevesi [46]

\subsection{Verilerin Entegrasyonu}

Ekotoksikogenomikte anahtar hedef, farklı çalışmalardan ve analitik platformlardan gelen verileri daha zengin ve biyolojik olarak bir hücrenin, organın veya organizmanın toksikolojik yanıtını daha belirginleşmiş kavrama zemininde birleștirmektir. Örneğin, bir amaç protein fonksiyonları ile gen ekspresyonu arasında veya belli metabolize edici enzimler ile seruma veya küçük metabolit gruplarının organizmanın idrarındaki ekskresyon arasındaki etkileşimi tanımlayabilir.

Farklı alanlardan gelen proteomik, transkriptomik veya metabonomik gibi verilerin entegrasyonu rapor edilmiştir. Bu deneylerde, doku örnekleri aynı birey hayvanlardan ya da farklı teknolojiler kullanarak paralelde benzer olarak uygulanan hayvanların analizinden elde edilmiştir. Bununla birlikte, farklı çalışmalardan gelen veriler sadece farklı açılardan yanitlayıcı transkriptlerin son listesindenden ya da elde edilen protein profillerinden elde edilirler [47]. Global proteomik veya metabonomik çalışmalarından elde edilen iki boyutlu jelden spot yoğunluğu veya nükleer manyetik rezonans ile (NMR) metabonomiklerin iz verileri gibi tecrübeler; bize küme yada temel bileşenler analizlerininin, transkripsiyon analizlerine çok benzer şekilde moleküler ekspresyonun evrensel işaretlerden elde edilebileceğini anlatır [48]. Eğer biyolojik örnekler, benzer ekspresyon karakteristiği gösteren, kendilerine has kümelerine ayrılırlarsa, sonraki çabalar bu örneklerde eksprese olan yeni protein ya da metabolitlerin farkına vardırabilir [11]. Sonraki aşamalar potansiyel biyobelirteçler ya da toksikojik yanıtın temelini oluşturmada araç olarak bu protein ya da metabolitleri değerlendirmeye yönlenir. Gen karşılaştırmaları, kamu veri tabanındaki protein ve metabolik veriler biyolojik sistemlerin fonksiyonlarının ve çevresel etkenlere yanıtların nasıl olduğu hususunda teşvik edici evrensel anlayış için değerli olacaklardır [49-53].

$\mathrm{Bu}$ yazılım havuzları geliştiğinde; deneyler, farklı deney dizaynları kullanarak ancak benzer toksisite son noktası veya toksikantın benzer sinıfindan bir parametreyi hedefleyerek tamamen başka kaynaklardan birikecektir. $\mathrm{Bu}$ durumlarda, veri tarama meydana gelmeden önce, ilgili çalışmalardan gelen veri tabanlarının entegrasyonu önemlidir. Biriken veri setlerinin değerini maksimize etmek için, yazılım havuzları farklı teknolojik alanlardan gelen verilerin entegrasyonu sağlanmalıdır [41]. Zira her bir gruptaki (domain) veri tiplerinin standart bir temsili, etkili ve tutarlı depolama, erişim, analiz, karşılaştırma ve veri değişimi için ön koşuldur. Gelişim sürecinde uluslararası standarları düzenleyen gruplar MGED (Microarray Gene Expression Data Society) veya RSBI'dir (Reporting Structure for Biological Investigations). Bundan sonra ise, düzenleme kuruluşlarının üyeleri, sanayiden, akademik ve idari laboravuarlardan gelen biliminsanlarıla beraber çalışarak, ILSI (International Life Science Institute) Genomik Komitesi ve Clinical Data Interchange Standards Consortium'da değişim, analiz ve transkriptomik verinin yorumlanması gibi durumlar için standart geliştirilmeye çalışır.

Bu durumu temellendirerek, toksikogenomik kavramının genişletilmesine yönelik, bunu PBPK (Fizyoloji Bazlı 
Farmakokinetik) ve PD (Farmakodinamik) modellemeleri gibi rekabet edici yaklaşımlarla birleştiren bir öneri söz konusudur [54]. PBDK modellemeleri, test ajanı dozunun kantitatif tahminlerini ya da hedef dokuda mevcut olan metabolitleri sağlamada kullanılabilir. Dolayısıyla, uygulama sonrası herhangi bir zamanda moleküler ekspresyon profillerini göz önüne almak başlangıç dozu, maruz kalma zamanına bağlı ya da toksikant indüklenmiş fenotipi referans almada düşünülebilir. Gen, protein ve metabolit ekspresyonu arasındaki ilişkiler, hem ajanın uygulanan dozunun fonksiyonu olarak hem de birbiri ardına gelen çeşitli doku kompartımanlarında meydana gelen kinetik ve dinamik doz - cevap doz - yanıt davranışları olarak tanımlanabilir. $\mathrm{Bu}$ modeller, transkriptom, proteom ve metabolomun bizzat kendileri dinamik sistemler olduklarından, değerlendirmede hesaba katılmalıdır. Bu nedenle bu -omik profilleri, gün içinde bir zaman ya da besin gibi önemli çevresel etkenlere tabi olurlar. Ayrıca, NIEHS Environmental Genome Project, genlerdeki çevresel maruz kalma, detoksifikasyon ve onarımda önemli TNPleri (Tek Nükleotid Polimorfizmi) tanımlama amacındadır. Toksikogenomik bilgiyi bu şekilde TNPler gibi dikkate değer noktalarla getirilebilecek analizler, organizmaların verdikleri yanıtlarda bize resmi daha büyük bir çerçevede bakmamıza olanak sağlayabilir (Şekil 3).

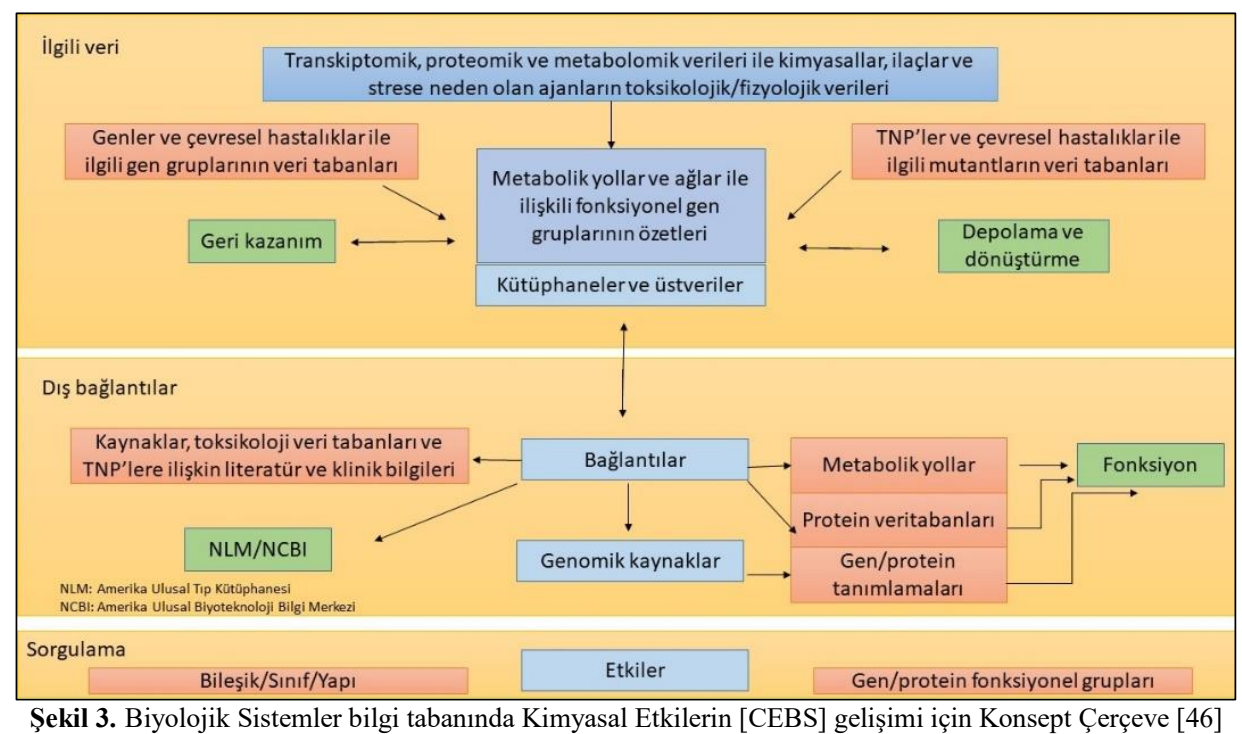

\subsubsection{Ekotoksikogenomik Yaklaşım}

Ekspresyon profilleme gibi genomik analizler bir organizmanın çevresel etkenler ile olan reaksiyonunu inceler. İlk olarak, organizma, vücuduna giren ve vücut içerisinde dağılan kimyasala maruz kalır. Spesifik hücresel hasarlarla sonuçlanan, bir şekilde kendine has kimyasal özelliklerinde kirletici hücreler ve hücresel komponentler ile etkileşime girer. Yanıt olarak; organizma kirleticiye, genin ekspresyon değişimini, protein seviyelerini veya metabolik konsantrasyonları içeren çoklu seviyelerde reaksiyon gösterir [55]. Bu değişimler, örneğin organizmayı önemli stres kaynaklarından korumada yardım ya da bunun yan etkilerini azaltmak gibi biçimlerde olabilir. Genler, kirleticinin etki mekanizmasına bağımlı ve spesifik olarak değiştirilen belirli setlerden (ya da protein veya metabolitlerin) oluşur [55]. Yanıtın önemsenen örüntüsü, spesifik bir etki mekanizmasını ve kirleticiyi bir parmak izi gibi temsil edebilir.

Ekotoksikologlar için DNA mikroçipleri, uygun genomik araçlardan biridir. Gen ekspresyon mikroçipleri, her substrat üzerinde genellikle DNA parçalarının en yakın haliyle düzenlenmiş analizlerinden oluşur (örneğin 100 mikron). Her parça genellikle spesifik bir gen için bir araştırmayı temsil eden farklı bir DNA molekülünden oluşur. Mikroçipler, araştırıcının tek bir RNA örnekli tahlili üzerinde tüm genin ekspresyonunu temsil ederek sorgulamasını sağlar. cDNA mikroçipleri, bireysel klonlanmış cDNAların PZR amplifikasyonundan gelen DNAları içerir. Sonuç olarak, probun uzunluğu oldukça çeşitli olabilir. Fragmentler üzerindeki yüksek yoğunlukta DNA noktalarını yazmada robot yazıcılar kullanılır. DNA mikroçiplerinin yakın zamandaki bir tipi, spesifik transkriptler için $50-70$ birimlik oligonükleotit problarından oluşur. cDNA çiplerine zıt olarak da her transkript için sekans bilgisi gereklidir. Bu oligonükleotitler cam parça üzerinde direk olarak sentezlenebildiği gibi önceden imal edilerek, farklı polimerler üzerinde de işaretlenebilir [56]. Afimetrik çipler ise birkaç kısa oligolarda belli bir gen için prob olarak kullanılan başka bir yaklaşımı temsil eder.

\subsection{Verilerin Entegrasyonu}

Ekotoksikogenomik, kirleticilere ilişkin bilinmeyen toksisiteyi, sürekliliği, çevresel akıbeti, taşınımı ve kompleks karışımlardaki varlığı gibi zorluklarda yardımc1 olabilir. Ekotoksikogenomiğin etki mekanizmaları [MOA=Mode of Action] bilgilendirmede ve çevrede kimyasala maruz kalmayı tahmin etme çalışmaları için iki potansiyel uygulama üzerinden gitmek yararlı olacaktır. Bunlardan birisi NOTEL [Transkripsiyonel Etki Gözetlenmeyen Seviye] ve bir diğeri genomik bazlı TIE dir [Toksisite Tanımlama Değerlendirmesi]. $\mathrm{Bu}$ ve benzeri çalışmaların 
yürütülmesi ileride bu tip çalışmaları daha önemli su kalitesi, çevre sağlığı gibi hususlarda gözlem parametreleri olarak düşünülmesini kuvvetle sağlayacaktır.

\subsubsection{Transkripsiyonal etki gözlenmeyen seviye [NOTEL]}

NOTEL kavramı, bir kimyasalın gen ekspresyonunda kayda değer değişim ile sonuçlanmayan dozu olarak tanımlanabilir [57]. Lobenhofer ve ark., önce bu konsepti bir MCF - 7 hücresi [bir östrojen yanıt kanser hücresi hatt1] çalışmasında önermiş, burada iki düşük doz, bir fizyolojik doz ve bir de sitotoksik doz içeren dört farklı konsantrasyona maruz kalmayı çalışmışlardır. $\mathrm{Bu}$ çalışmada, 2000 aday genin hiçbirinde kayda değer değişim ile eksprese olmayan iki düşük dozu vurgulamışlar ve bunların etkene transkripsiyonal yanıt için bir dönüm noktası konsantrasyonu olarak NOTEL terimini önermişlerdir. Buradaki önemli husus, herhangi bir hücresel taşıma bozukluğu gen ekspresyonunda kayda değer bazı değişimlere neden olmalıdır; böylece NOTEL değeri olarak gerçek transkripsiyonal etki gözlenmeyen seviye hesaplanabilir. Bazı araştırıcılar, NOTEL'in kontaminasyon izlemede ve hatta düzenleme standartlarını kurmada kullanılabileceğini önermişlerdir [58].

Gen ekspresyon değişimleri her zaman toksisiteyi belirtmeyebilir, bazen de dengeleyici (telafi edici) yanıtları temsil edebilir. Çevresel izlemede NOTEL'in potansiyel rolü kimi çalışmalarda gösterilmiştir. Poynton ve ark., düşük seviyede metal konsantrasyonlarında, D.magna'da çok az da olsa genlerin farklı eksprese olabildiklerini göstermiştir [59]. Daha sonra terk edilmiş iki bakır madeninden örneklerinin gen ekspresyon paternleri karşılaştırılmış ve bakır yatakların kaynağa yakın yerlerinden gelen gen ekspresyon örüntüleri, çok düşük konsantrasyonları ile de çok az da olsa farklı biçimde eksprese olan genler ile sonuçlandığı gösterilmiştir: Atlantik yıllıkbalığının (Fundulus heteroclitus) hedef tür olduğu New Bedford limanındaki (ABD) iyileştirmenin etkinliğinin izlenmesinde mikroçiplerden yararlanılan çalışmada Crawford ve ark. (2019), lipid homeostasisindeki Poliklorinli Bifenil (PCB) ve gen ekspresyonunun ilişkili olduğunu göstermişlerdir[60]. Yine yavru Atlantik yıllıkbalıklarında hepatik yanıtların izlendiği çalışmada kirliliğe adapte olmada eksprese olan gen yanıtları da bu konu ile ilgili bir diğer örnektir. [61].

\subsubsection{Karışımlara genomik toksisite tanımlama değerlendirme yaklaşımı}

Doğal ortamlarında, organizmalar sadece bir bileşiğe değil, çevre ve bireysel organizmalar ile etkileşimde olabilen bir kirletici karışımı ile maruz kalabilirler. Önceden vurgulandığı gibi, çevrede kirletici karışımlarını içeren kompleksler atık sularda bazılar saptanmıştır. Toksisite Tanımlama Değerlendirmesi (TTD) süreci sıklıkla kompleks karışımlardaki tekil kimyasallar ile filtrelenen ilişkili toksisite testlerinden yararlanıp, nedensel ajanları belirler. Toksisite tanımlamada güncel metotlar; bir ya da daha fazla toksikant sınıfindan kaldırılan, her manipülasyonu takip eden atık su toksisiste testleri ile eşleşmiş biyofizyolojik ayrışımı ve uygulamalarından yararlanır. Zaman ve maliyet olarak ilgili yürütülen bir TTD, bu bağlamda çok önemlidir [62] ve genelde bu yaklaşımlar, bazı atık sularda toksikantların genel sınıflarının ayrıștırılmasında başarılıdır; ancak tek bir kirletici değerlendirilmesi için böyle bir başarıdan bahsedilemez. Ek olarak, ayrışım yaklaşımları da karışımlarda sinerjistik yada antagonistik etkinin oluşturulabilmesi olarak değerlendirilmez. Çünkü bu metot, yillarca toksikant tanımlamada dayanak noktası olmuştur ve bir TTD yaklaşımı daha duyarlı, spesifik, süreli ve uygun maliyetli özellikleri ile daha net bir ifadedir.

Genomik, TTD için alternatif ve tamamlayıcı bir araç olarak önerilebilir. Gen ekspresyon profilleri bir kompleks atık suda nedensel ajanı belirleyebilir. Ayrıca karışımlardaki kimyasalların, üreme ve hayatta kalmada beklenmeyen sonuçlar ile etkileșebildikleri bilinmektedir [63]. Kimyasal kombinasyonlarının farklı etkilere sahip olmaları, o organizma üzerindeki gen ekspresyon profillerini etkileyen tekli kimyasallara kiyasla daha uygundur. Akut yada kronik biyo-sınamalardaki ek yanıta neden olan kimyasallar, ayrıca bir başlarına da additif ekspresyon profiline de sahip olabilir. Standart biyo-sınamalarda sinerjistik veya antagonistik etki gösteren kimyasalların kendine özgü ekspresyon profilleri olabilir ama tekli kimyasalların ekspresyon profillerini temsil etmezler. Örneğin, krom ve benzopiren içeren karışımın karaciğer tümör hücre hattına [hepatoma hücreleri] etkileri üzerine olan bir çalışmada, Liu ve ark. (2010), karışımın gen ekspresyon profilinin, tekil kirleticilerin, profillerinden farklı olduklarını bulmuşlardır [64]. Bununla beraber, bilinen bu iki transkripsiyonal yolları benzeyen karsinojen hedef, zit yönlendirmeler ile bir antagonistik yanıta neden olur. Böylece, karışımda bazı indüklenmiş gen benzopirenlerin baskılanması tahmin edilmiştir.

Krasnov ve ark. (2005), Cd, $\mathrm{CCl}_{4}$ ve piren olarak 3 model toksikantı araştırmıştır [65]. Düşük maruz kalma seviyelerinde ekspresyon profillerinin aditif olduklarını ve $\mathrm{Cd}$ ile piren ekspresyon profillerinin ayrılabileceklerini göstermişlerdir. Nanopartikül araştırmalarını içeren bir diğer çalışma ise nanopartikül ve yardımcı çözücüsünden dolayı etkiler arasında ayrım yapabilme imkanını göstermiştir. Fullerenlerin $\left(\mathrm{C}_{60}\right)$ ayrışması için partiküler hidrofobik özelliğe sahip, bir yardımcı çözücü ajan olan tetrahidrofurandan (THF) yararlanılır. Araştırmacılar, bu iki formulasyona maruz kalmanın ekspresyon profilleri benzer örüntüye sahip olsa da fullerenlerin ayrışmasında THF'nin toksik etkisi görece düşük kaldığını göstermişlerdir [66]. THF - $\mathrm{C}_{60}$ ve yalnız THF'ye maruz kalmanın ekspresyon profillerinin benzer olması görülen toksik etkileri ve sudaki THF degredasyon ürünlerinin bir sonucu olarak $\mathrm{C}_{60}$ a katkıyı ifade eder. Ancak bu öncül sonuçlara rağmen, DNA mikroçipleri TTD yaklaşımına bütünüyle entegre olmadan önce; gen ekspresyonları üzerinde karışımların etkilerinin anlaşılmasını sağlayan çok sayıda çalışmaya ihtiyaç olduğu açıktır. 


\subsection{Etki Mekanizmasını Anlamada Genomik Yaklaşım}

Ekspresyon profilleri ve diğer genom ifadelerin geniş yaklaşımları, toksikantların etki mekanizmasının [MOA] hipotezinin test edilebilirliğine yardımcı olmuş ve etki mekanizması bazlı olarak kimyasalların sınıflandırılmasına imkan sağlamıştır. Yeni gelişmekte olan kimyasallar için, MOA verileri kirletici ile en çok ilgili analizlerin ne olacağını belirlemede önemlidirler. Ek olarak, mekanistik veriler yeni gelişmekte olan kimyasalların muhtemel risk değerlendirmelerle ilgili bilgilendirmeye ilişkin gerekliliği de söz konusudur. Ayrıca mikroçipler de bu tip bilgi sağlamada önemli rol oynayabilecek bir potansiyele sahiptirler [67]. Mikroçip çalışmalarından MOA bilgisi sonucu çıkarmak için çok sayıda metot vardır. Zebra balığı beyninde nörofarmasötiklerin etkilerinin araştırıldığ son çalışmalara göre, bu balık türünde görülen etkiler memelilerdekine benzer bir örüntü göstermektedir $[68,69]$. Bundandır ki türler arası ekstrapolasyonlarla, balıklardan yararlanıp, bu ilaçların uzun dönemli etkileri hakkında tahminler yapabilmek mümkün olmuştur. Mikroçip çalışmalarından MOA araştırmaları için gelen diğer teknikler, Anbumani ve Kakkar tarafindan derlenmiştir [70]. Ayrıca gen ürünlerinin bilinen biyolojik metabolik yollara entegrasyonu, maruz kalmayla ilişkili metabolik, işaret verme (sinyalizasyon) yada farklı yanıtları ortaya çıkarabilir. Son olarak, gen ekspresyonun fizyolojik / fenotipik etkileri ile bağlantılı fenotipik tespitleme (referans noktası) nedensel sonuç çıkarma için destek sağlamada hayati derecede önemlidir. Buradaki bir amaç, bir sonuç tahmin etmede ve biyobelirteç olarak kullanılabilmesi, genlerin kümelenmelerinin tanımlanması olarak düşünülebilir.

GO, moleküler fonksiyonları, biyolojik süreçleri ve her genin hücresel bileşenlerini tanımlamada sistematik bir metottur [71]. GO Konsorsiyumu'ndan [http://www.geneontology.org] yararlanarak, araştırıcı "Hangi hücresel bileşenler yada biyolojik sistemler stres kaynağından etkileniyor?" sorusuna bir yanıt belirleyebilmek için bu sınıflandırma sistemini kullanabilir [72]. GO terimlerinin görevi farklı eksprese olmuş genlerin listesini ile daha büyük etkilere ve biyolojik süreçlere ilişkin bir fikir verip, bunların etki mekanizmasını açıklamada yer alması olarak ifade edilebilir. Östrojenik bileşiklerle ilgili çalışmalarda zebra balığında [Danio rerio] farklı organlarda östrojenlerden ve farmasötiklerden kaynaklanan etkileri tahmin etmede GO yaklaşımından yararlanılmıştır [73-76]. Bir diğer 17- $\beta$ östradiol ile ilgili mikroçip çalışmasında; koca galyan balığındaki [Pimephales promela] östradiol, toksisitenin muhtemel hedeflerini belirlemede GO koşulları kullanılmıştır. Bunlar kan pıhtılaşması, metabolizma, protein biosentezi, elektron transportu ve hücre büyümesinin düzenlenmesini içermektedir [77].

Bir kimyasala maruz kalmanın biyolojik sonuçlarının araştırıldığı bir diğer metot ise Kyoto Gen ve Genomların Ansiklopedisi [78] ve Gen Harita Belirlenimi [Annotasyonu] ve Metabolik Yol Profilleyicisi [79] gibi veri tabanlarından yararlanılan
Metabolik Yol Haritalamadır. Bu araçlar, araştırıcıya metabolik yollarda maruz kalma çalışmalarında farklı eksprese olmuş genlerin tanımlanarak haritalanması hususunda olanak sağlar. Bir genel bakış, potansiyel hedefleri ortaya çıarabilir ve metabolik yolun fonksiyonu üzerinde etkilerin tahmin edilmesine imkan sağlar. Villeneueve ve ark. (2007), metabolik yol analizlerini östrojenik bileşiklerin etkilerini anlamak için kullanmışlardır [80]. Villeneueve ve ark., koca golyan balığı üzerinde androjen fadrozolun etkilerinin ekotoksikogenomik çalışması bazlı bir hipotez öne sürerek, teleost beyin -hipofiz -gonadal aksisin bir grafiksel modelini kurmuşlardır. Onların modeli, beyin, hipofiz, karaciğer ve gonadlar üzerinde muhtemel risk değerlendirmeye yön vermede, moleküler yanitla yan etki bağlantısı için gerekli bir araç sağlar. Son olarak, bazı araştırıcılar tarafından önerildiği üzere, moleküler olayların referans noktasının zit fizyolojik sonuçları, mikroçip çalışmalarından gelen güvenilir MOA tahminleri için gereklidir [26-28,58,81-83]. Fenotipik referans noktası, moleküler olayları göstermeyle birlikte toksikolojik sonuçlar yada etken durumu ile bağlantı sağlar. Fenotipik bağlantıyı göstermek için, araştırmacılar geleneksel toksikolojik son noktaları mikroçip çalışmalarını da dahil etmişlerdir. Zebra balıklarında çevresel ilişkili konsantrasyon seviyelerinde etinilestradiolün (EE2) etkilerine ilişkin bir çalışma, EE2 nin hem erkeklerde hem de dişilerde gamet üretimini yan etki olarak etkilediğini ortaya çıkarmıştır. Çeşitli gen ailelerinin disregülasyonu (düzenleme bozukluğu) her iki cinsiyette gamet üretim bozukluğu için potansiyel bir mekanizma açıklamıştır [84]. Buna benzer şekilde çok sayıda türde endokrin bozucuların etkisi genomik düzeyde gösterilmiştir [85,86]. Bu sayede araştırıcılar, endokrin bozucu süreçlerde yer alan reseptörlerin detaylı moleküler karakterizasyonları ile olan gen ekspresyon çalışmalarından faydalanarak, bu gelişmenin bir fenotipik yanıt üretmede moleküler olayların rolünün anlaşılmasını sağlamışlardır.

\subsection{Genler ile Populasyonlar Arasında Kurulan Köprü Olarak "Ekotoksikogenomik"}

Çevresel risk değerlendirmede kullanılan standart ekotoksisite testlerinin cevaplayamadığı sorulara ekotoksikogenomik bir çözüm olabilir. Gen ekspresyonundaki değişimler, duyarlı son noktalar olup, çevresel etkenler için birer erken uyarı belirteçleri olabilir. Ekotoksikogenomik, düşük seviyede biyolojik organizasyonlara odaklanmayı yeğler. Buradaki amaç, hem mekanistik hem korelatif olarak gen ekspresyon yanıtları ve popülasyon seviye yanıtları arasında bağlantıları keşfetmektir. Ancak LOEC [en düşük etki gözlenen konsantrasyon] ve NOEC [hiç etki gözlenmeyen konsantrasyon] değerlerinin indikatör olarak saptanmasında veri eksikliği sürmektedir [87-89]. Tutarlı bir çerçeve oluşturmak için sürecin her seviyesinde en az bir son nokta olmalıdır.

Ekotoksisite testlerinde siklıkla kullanılan hedefler hayatta kalabilip, üreme yeteneğinde olan bireylerdir. $\mathrm{Bu}$ yetenekteki organizmaların sağladıkları erken uyarı sistemi ile kimyasal etkilerin düşük konsantrasyonlarda 
ve üreme ile alakalı veya morfolojik etkileri görünür olmadan tespit edilebilir.

\section{POTANSIYYL YARARLAR}

Tartışmasız olarak, kimyasallara ilişkin insan yada ekolojik risk değerlendirmesi üzerinde genomik verinin en kayda değer etkisi, toksisite metabolik yollarını veya etki mekanizmalarını (MOA) iyi bir tanımlama olarak ifade edilebilir. Örneğin, dünya genelindeki düzenleyici kuruluşlar, hipotalamik - hipofiz- gonadal [HPG] bölgeler veya hipotalamik - hipofiz - tiroid (HPT) bölgeler arası metabolik yolu ayrıştırmayı sağlayan endokrin bozucu kimyasalların potansiyel risklerine odaklanır [90-93]. Olanaksız değilse de, uzun - dönem deneyler ile potansiyel yan etkilerini de değerlendirerek endokrin bozucu kimyasalları (EBK) sınamak pek kolay değildir. $\mathrm{Bu}$ nedenle, bazı durumlarda görece iyi açıklanmış olan EBK'lerin potansiyeli bakımından kimyasalların öncelik verilen listesini oluşturma ile ilgili bir yayıma ihtiyaç vardır. Eğer in vitro veya in vivo sistemlerle kisa dönemli testler, bilinen etki mekanizmalarına (MOA) bağlı EBKlere genomik yanıtların profillerinin geliştirilmesi için kullanılabilirse, bu testlerin sonuçları öncelik verilen ama bilinmeyen etki mekanizmalı (MOA) kimyasallar için de daha fazla özen gösterilerek uzun soluklu çalışmalarda kullanılabilecektir.

Ayrıca, genomikler bir bileşiğin beklenmeyen etki mekanizmalarına sahip olup olmamasına ilişkin olarak iç yüzünü kavramayı sağlayabilir. Örneğin; pestisit tescili gibi düzenleme şartlarında, a priori (olası) bilgi muhtemel toksik etki mekanizmalarıyla ilgilidir. Bununla birlikte, kimyasallar genellikle çok sayıda metabolik yol vasitasiyla toksisiteye neden olur. Günümüzde, pestisit düzenlemeleri çok sayıda tür ve "kaçırılmaması gereken" beklenmedik toksisite metabolik yollarından emin olunan son noktalar ile olan çok sayıda farklı tipte teste gereksinir. Bunlar, zaman alan ancak sonunda değerli katkıları olan çok büyük çapta veri birikimi sağlayacaktır. Bununla beraber, genomik yanıt odaklı kısa dönemli sınamalar, belirlenmiş etki mekanizmaları ile "referans" toksikantlardan elde edilen bilgiler ile deney kimyasallarından gelen verilerin karşılaştırılması kullanılarak beklenmeyen toksisite metabolik yollarını tanımlamaya yardımc olabilir $[94,95]$. Bu tip analizler ile elde edilen kazanımlar, deney tasarımlarını ve verilen kimyasal en uygun şekilde sınamasındaki son noktalarını özelleştirmede kullanılabilir. Böylece, daha iyi hedef etki mekanizmalarıyla genomiğin kullanımı, risk değerlendirmeyi etkileyen deneylere ilişkin kaynakların yatırımında odaklamaya yardımcı olabilir.

MOA'nın daha iyi tanımı ayrıca risk değerlendirmedeki belirsizlikleri indirgemek için bilgiler de sağlayabilir. Örneğin, risk değerlendirme ile ilgili önemli kaynaklar, kimyasal karışımların toksisitesini tahminlemeyi içerir. Genomik profiller, benzer olan etkilere karşı benzer olmayan etki mekanizmaları ile ve dolaylı aditif etkiler için seçici "atık" kimyasalları ile bileşikleri tanımlamada kullanılabilir. Kimyasalların etkilerinin türler boyunca ekstrapolasyonu, genomik vasıtasıyla etki mekanizmalarını iyi anlamada bir diğer alan olarak faydalı kavramlar sağlayabilir [96]. Toksikogenomik teknikler, türler boyunca benzerlikleri ve ayrışımları tanımlamada öncülük edebilir; dolayısıyla kimyasal tehlikelerin ekstrapolasyonunun onaylanmasına yardımcı olma, bir türden diğerine teknik olarak geçerlidir. Son olarak; MOA bilgisi, tanısal değerlendirmenin önemli kavrayışlarını sağlayabilir. Çoğu çevresel düzenlemede, organizmalar hem kimyasal hem de kimyasal olmayan çeşitli stres etkenine maruz kalır. $\mathrm{Bu}$ yüzden, istenilmeyen etki durumlarında meydana gelen etkilere neden olan stres etkenlerini tanımlamada zorlayıc1 olabilir.

$\mathrm{Bu}$ durumun karşılaştırmalı basit örneği, bir düzenleyici perspektif olan atık su toksisitesini içerir. Bununla beraber, bir atık su toksik varsayıldığında, sebep olabilecek ajanların tanımlanması kimyasal karışımlarının kompleksliğinin varlığından dolayı son derece zor olabilir [karışık matriksteki kirletici biyoetkinliğiyle ilgili belirsizlikler olduğu gibi]. Bu durum, biyolojik bazlı basit fraksiyon prosedürlerinin gelişimine öncülük ederek, basit toksisitelerden sorumlu spesifik kimyasalları belirlemeye yardımcı olur [97]. Bu yaklaşımlar, çeşitli türlere, son noktalara ve test matrislerine başarıyla adapte olur. Toksikogenomik veriler kullanarak, kirleticilerin kompleks maruz kalan organizmalarda biyolojik olarak toksisite metabolik yollarını tanımlama, TTD sürecine iyi bir destek olabilir. Örneğin, günümüzde, toksisite verileri bulunabilir veya bir küçük karşılaştırmalı altküme ile kaynak gereksiğinden dolayı yeni kimyasallar üretilebilir [98]. REACH programi (Registration, Evaluation, Authorisation and Restriction of Chemicals) önümüzdeki yıllarda, binlerce kimyasalın güvenilir değerlendirmelerine gereksinerek bu belirsizliklere hitap etme arayışında fayda sağlaycaktır [99,100]. Toksikogenomik teknikler; çok sınırlı örneklemlerden gelen çoklu potansiyel toksisiteyi yansıtan ilgili taranan verilerle bir arada değerlendirildiğinde güzel sonuçlar verebilir. Bu yaklaşım kaynakları en uygun şekilde kullanarak, hayvan kullanımını da sinırlar. Dolayısıyla kimyasallar için risk değerlendirmeleri, genomikteki geniş uygulamaları ile kısa dönemde akla uygun olarak beklenilebilen bir gelişime geçirmese de bu yaklaşım kavramsal olarak sağlamdır.

\subsection{Ekotoksikogenomiğin Geleceği}

Yeni ekotoksikogenomik metotlarının gücü ve toksikolojide devrim yapma potansiyelleri vardır. Protein antikorları ile toksikolojik olarak ilişkili ve çok sayıda küçük molekülün profil tayinlerinin gelişiminde gaz kromatografisi, sivi kromatografi veya kütle spektrometre kullanilır [101]. Toksikoproteomik araştırma, tanımlamada, ölçmede ve protein ile diğer biyobelirteçlerin değerlendirmesinde şu an mevcut olanlardan daha tutarlı, duyarlı ve spesifik bir düzeye tartışmayı taşımayı öngörür. Metabonomik araştırmalar "metabolit parmak izleri” gibi spesifik kimyasallara, çevresel maruz kalmaya yada hastalığa neden olan stres etkenleri ile ilgili durumlarda önemli metabolik olayların 
sekansında küçük endojen moleküllerinin seviyelerindeki değişimlerin tanımlanmasında yardımcı olacaktır. $\mathrm{Bu}$ aşamadan sonra göz önüne alınacak durumlar bireysel genotipler, yaşam biçimleri, yaş, maruz kalma geçmişi gibi çevresel maruz kalmaya toksikogenomik yanıtları değerlendirmeler biçiminde olacaktır [102,103]. Ekotoksikogenomik, çevresel gerçekçi doza genomik yanıtların global gözlemi vasıtasıyla toksikoloji ile ilgili çalışmalarda artan bir değer olarak yerini alacaktır. Çok sayıda ve çok sınıftaki ajanların etki mekanizmaları betimleyecek ve belli tür ve populasyon alt gruplarının etki mekanizmalarını yorumlayabilen eşsiz genetik özellikleri gösterebilecektir. Bir tür içindeki soylarla ilgili çalışmalar, o kimyasala duyarlı yada dirençli olmaları ile spesifik hastalıklarda bu kimyasalların neden olma durumlarını değerli kılan yolları göstereceklerdir [82]. $\mathrm{Bu}$ düşünceyi hem ana korunmuş biyolojik süreçlere hem de farklı türlerdeki görünen toksikolojik yanıtlar ile genişletmek; genetik hassaslığın karşılaştırmalı kavranmasını ve muhtemel hastalık sonuçlarının kapsamlı ele alınmasını sağlayacaktır.

Sonuç olarak -omik teknolojilerinden yararlanılan bu tip uygulamalar, toksisite mekanizmasını kapsamlı olarak anlamamızı sağlayarak in vivo ve/veya in vitro deney sistemleri ile entegre olmuş toksikogenomik veri tabanları olarak hastalık etiyolojisinin geniş biçimde tamamlanmasını geliştirecektir. Doz, zaman, hedef doku ve türler arasında fenotipik yalınlık gibi içeriklerden toplanan geni protein, metabolit değişim verileri gen çevre etkileşimlerinde genetik ve moleküler bazlı değerlendirme gerektiren karşılaştırmalı bilgileri sağlayacaktır. Böylece toksikoloji, biyolojik türler, kimyasal sınıflar ve hastalık sonuçları arasında bilimsel keşfi kolaylaştıran bir bilgi bilimi olarak ortaya çıkacaktır. Biyoinformatik metotlarının ve veri toplama araçlarının gelişimi 21. yüzyılda çevresel etkilere maruz kalma ile ilgili hastalıkların yan etkilerinden korunma yada azaltılmasında ekotoksikogenomik, multidisipliner kimliği ile hem erken uyarı değerlendirilmesini hem de kirleticiye maruz kalmanın ekosistemde oluşturduğu risklerin moleküler düzeyde etki mekanizmalarının açıklanmasını sağlayan bir bilim dalı olarak yerini alacaktır.

\section{Teșekkür}

$\mathrm{Bu}$ çalışmasının değerlendirilmesinde yerinde tespitleri ve yönlendirici soruları ile katkı sağlayan değerli hakemlere teşekkür ederim.

\section{KAYNAKLAR}

[1] Snape JR, Maund SJ, Pickford DB, Hutchinson TH. Ecotoxicogenomics: the challenge of integrating genomics into aquatic and terrestrial ecotoxicology. Aquatic toxicology. 2004;67(2):143-54.

[2] Nuwaysir EF, Bittner M, Trent J, Barrett JC, Afshari CA. Microarrays and toxicology: the advent of toxicogenomics. Molecular Carcinogenesis: Published in cooperation with the University of Texas MD Anderson Cancer Center. 1999;24(3):153-9.
[3] Fielden MR, Zacharewski TR. Challenges and limitations of gene expression profiling in mechanistic and predictive toxicology. Toxicological sciences. 2001;60(1):6-10.

[4] Thomas RS, Rank DR, Penn SG, Zastrow GM, Hayes KR, Pande K, vd. Identification of toxicologically predictive gene sets using cDNA microarrays. Molecular Pharmacology. 2001;60(6):1189-94.

[5] Hamadeh HK, Bushel PR, Jayadev S, Martin K, DiSorbo O, Sieber S, vd. Gene expression analysis reveals chemical-specific profiles. Toxicological Sciences. 2002;67(2):219-31.

[6] Tennant RW. The National Center for Toxicogenomics: using new technologies to inform mechanistic toxicology. Environmental health perspectives. 2002;110(1):A8-10.

[7] Ulrich R, Friend SH. Toxicogenomics and drug discovery: will new technologies help us produce better drugs? Nature Reviews Drug Discovery. 2002;1(1):84-8.

[8] Olden K. Genomics in environmental health research-opportunities and challenges. Toxicology. 2004;198(1-3):19-24.

[9] Lettieri T. Recent applications of DNA microarray technology to toxicology and ecotoxicology. Environmental health perspectives. 2006;114(1):49.

[10] Sanchez BC, Ralston-Hooper K, Sepúlveda MS. Review of recent proteomic applications in aquatic toxicology. Environmental toxicology and chemistry. 2011;30(2):274-82.

[11] Dorts J, Kestemont P, Marchand P-A, D'Hollander W, Thézenas M-L, Raes M, vd. Ecotoxicoproteomics in gills of the sentinel fish species, Cottus gobio, exposed to perfluorooctane sulfonate (PFOS). Aquatic Toxicology. 2011;103(1-2):1-8.

[12] Gomes T, Pereira CG, Cardoso C, Pinheiro JP, Cancio I, Bebianno MJ. Accumulation and toxicity of copper oxide nanoparticles in the digestive gland of Mytilus galloprovincialis. Aquatic Toxicology. 2012;118:72-9.

[13] Vidal-Dorsch DE, Bay SM, Moore S, Layton B, Mehinto AC, Vulpe CD, vd. Ecotoxicogenomics: Microarray interlaboratory comparability. Chemosphere. 2016;144:193-200.

[14] Abbas A, Valek L, Schneider I, Bollmann A, Knopp G, Seitz W, vd. Ecotoxicological impacts of surface water and wastewater from conventional and advanced treatment technologies on brood size, larval length, and cytochrome P450 (35A3) expression in Caenorhabditis elegans. Environmental Science and Pollution Research. 2018;25(14):13868-80.

[15] Campos B, Fletcher D, Piña B, Tauler R, Barata C. Differential gene transcription across the life cycle in Daphnia magna using a new all genome custommade microarray. BMC genomics. 2018;19(1):370.

[16] Campana O, Wlodkowic D. Ecotoxicology goes on a chip: embracing miniaturized bioanalysis in aquatic risk assessment. Environmental science \& technology. 2018;52(3):932-46. 
[17] Prat O, Degli-Esposti D. New Challenges: Omics Technologies in Ecotoxicology. Içinde: Ecotoxicology. Elsevier; 2019. s. 181-208.

[18] Lee B-Y, Choi B-S, Kim M-S, Park JC, Jeong C-B, Han J, vd. The genome of the freshwater water flea Daphnia magna: A potential use for freshwater molecular ecotoxicology. Aquatic Toxicology. 2019;210:69-84.

[19] Fröhlich E. Role of omics techniques in the toxicity testing of nanoparticles. Journal of nanobiotechnology. 2017;15(1):84.

[20] Simões T, Novais SC, Natal-da-Luz T, Devreese B, de Boer T, Roelofs D, vd. An integrative omics approach to unravel toxicity mechanisms of environmental chemicals: effects of a formulated herbicide. Scientific reports. 2018;8(1):1-12.

[21] Martínez R, Navarro-Martín L, Luccarelli C, OrtizVillanueva E, Codina AE, Raldúa D, vd. Applying omic techniques to unravel distinct pathways of PFOS toxicity in zebrafish eleutheroembryos. 2019;

[22] Krizkova S, Kepinska M, Emri G, Rodrigo MAM, Tmejova K, Nerudova D, vd. Microarray analysis of metallothioneins in human diseases-A review. Journal of pharmaceutical and biomedical analysis. 2016;117:464-73.

[23] Searfoss GH, Jordan WH, Calligaro DO, Galbreath EJ, Schirtzinger LM, Berridge BR, vd. Adipsin, a biomarker of gastrointestinal toxicity mediated by a functional $\gamma$-secretase inhibitor. Journal of Biological Chemistry. 2003;278(46):46107-16.

[24] Ampe F. The use of nanopore sequencing in ecotoxicology. Ghent University; 2019.

[25] Bláha L, Hofman J. Ecotoxicology of Environmental Pollutants. Içinde: Advanced NanoBio Technologies for Water and Soil Treatment. Springer; 2020. s. 549-72.

[26] Poynton HC. Insights from 'Omics on the Exposure and Effects of Engineered Nanomaterials on Aquatic Organisms. Içinde: Ecotoxicology of Nanoparticles in Aquatic Systems. CRC Press; 2019. s. 189-207.

[27] Caballero-Gallardo K, Olivero-Verbel J, L Freeman J. Toxicogenomics to evaluate endocrine disrupting effects of environmental chemicals using the zebrafish model. Current genomics. 2016;17(6): s515-27.

[28] Messerlian C, Martinez RM, Hauser R, Baccarelli AA. "Omics" and endocrine-disrupting chemicals - new paths forward. Nature Reviews Endocrinology. 2017;13(12):740.

[29] Oliveira E, Barata C, Piña B. Endocrine disruption in the omics era: new views, new hazards, new approaches. The Open Biotechnology Journal. 2016;10(1): s20-35.

[30] Kim B-M, Kim J, Choi I-Y, Raisuddin S, Au DW, Leung KM, vd. Omics of the marine medaka (Oryzias melastigma) and its relevance to marine environmental research. Marine environmental research. 2016;113:141-52.

[31] Lv X, Xiao S, Zhang G, Jiang P, Tang F. Occurrence and removal of phenolic endocrine disrupting chemicals in the water treatment processes. Scientific reports. 2016;6(1):1-10.

[32] Mennigen JA, Thompson LM, Bell M, Santos MT, Gore AC. Transgenerational effects of polychlorinated biphenyls: 1. Development and physiology across 3 generations of rats. Environmental Health. 2018;17(1):18.

[33] Chen H, Zhao L, Yu QJ. Determination and reduced life expectancy model and molecular docking analyses of estrogenic potentials of $17 \beta$ estradiol, bisphenol $\mathrm{A}$ and nonylphenol on expression of vitellogenin gene (vtg1) in zebrafish. Chemosphere. 2019;221:727-34.

[34] Rao MS, Van Vleet TR, Ciurlionis R, Buck WR, Mittelstadt SW, Blomme EA, vd. Comparison of RNA-seq and microarray gene expression platforms for the toxicogenomic evaluation of liver from short-term rat toxicity studies. Frontiers in genetics. 2019;9:636.

[35] Gismondi E. Identification of molt-inhibiting hormone and ecdysteroid receptor cDNA sequences in Gammarus pulex, and variations after endocrine disruptor exposures. Ecotoxicology and environmental safety. 2018;158:9-17.

[36] Salama RM, Abd Elwahab AH, Abd-Elgalil MM, Elmongy NF, Schaalan MF. LCZ696 (sacubitril/valsartan) protects against cyclophosphamide-induced testicular toxicity in rats: Role of neprilysin inhibition and lncRNA TUG1 in ameliorating apoptosis. Toxicology. 2020;152439.

[37] Jiang $\mathrm{W}$, Zhao $\mathrm{H}$, Zhang L, Wu B, Zha Z. Maintenance of mitochondrial function by astaxanthin protects against bisphenol A-induced kidney toxicity in rats. Biomedicine \& Pharmacotherapy. 2020;121:109629.

[38] Osorio D, Pinzón A, Martín-Jiménez C, Barreto GE, González J. Multiple pathways involved in palmitic acid-induced toxicity: A system biology approach. Frontiers in neuroscience. 2020;13:1410.

[39] Sharma N, Saifi MA, Singh SB, Godugu C. In vivo studies: toxicity and biodistribution of nanocarriers in organisms. Içinde: Nanotoxicity. Elsevier; 2020. s. 41-70.

[40] Yauk CL, Harrill AH, Ellinger-Ziegelbauer H, van der Laan JW, Moggs J, Froetschl R, vd. A crosssector call to improve carcinogenicity risk assessment through use of genomic methodologies. Regulatory Toxicology and Pharmacology. 2020;110:104526.

[41] Lemos MF, Soares AM, Correia AC, Esteves AC. Proteins in ecotoxicology-how, why and why not? Proteomics. 2010;10(4):873-87.

[42] Veldhoen N, Ikonomou MG, Helbing CC. Molecular profiling of marine fauna: integration of omics with environmental assessment of the world's oceans. Ecotoxicology and environmental safety. 2012;76:23-38.

[43] Zhang Q, Li J, Middleton A, Bhattacharya S, Conolly RB. Bridging the data gap from in vitro toxicity testing to chemical safety assessment through computational modeling. Frontiers in public health. 2018;6:261. 
[44] Udofia UU, Edet UO, Antai SP. Potential Benefits of Applying "Omics" Technology in Cleaning up Incessant Crude Oil Spillages in the Niger Delta Region of Nigeria. Advances in Research. 2018;18.

[45] Campos A, Tedesco S, Vasconcelos V, Cristobal S. Proteomic research in bivalves: towards the identification of molecular markers of aquatic pollution. Journal of Proteomics. 2012;75(14):4346-59.

[46] Waters MD, Fostel JM. Toxicogenomics and systems toxicology: aims and prospects. Nature Reviews Genetics. 2004;5(12):936-48.

[47] Hines A, Staff FJ, Widdows J, Compton RM, Falciani F, Viant MR. Discovery of metabolic signatures for predicting whole organism toxicology. Toxicological Sciences. 2010;115(2):369-78.

[48] Nair PMG, Choi J. Identification, characterization and expression profiles of Chironomus riparius glutathione S-transferase (GST) genes in response to cadmium and silver nanoparticles exposure. Aquatic toxicology. 2011;101(3-4):550-60.

[49] Dondero F, Banni M, Negri A, Boatti L, Dagnino A, Viarengo A. Interactions of a pesticide/heavy metal mixture in marine bivalves: a transcriptomic assessment. BMC genomics. 2011;12(1):195.

[50] Choi JS, Kim R-O, Yoon S, Kim W-K. Developmental toxicity of zinc oxide nanoparticles to zebrafish (Danio rerio): a transcriptomic analysis. PLoS One. 2016;11(8).

[51] Morgens DW, Wainberg M, Boyle EA, Ursu O, Araya CL, Tsui CK, vd. Genome-scale measurement of off-target activity using Cas9 toxicity in high-throughput screens. Nature communications. 2017;8(1):1-8.

[52] Hook SE, Mondon J, Revill AT, Greenfield PA, Smith RA, Turner RD, vd. Transcriptomic, lipid, and histological profiles suggest changes in health in fish from a pesticide hot spot. Marine environmental research. 2018;140:299-321.

[53] Davis AP, Grondin CJ, Johnson RJ, Sciaky D, McMorran R, Wiegers J, vd. The comparative toxicogenomics database: update 2019. Nucleic acids research. 2019;47(D1):D948-54.

[54] Aguayo-Orozco A, Taboureau O, Brunak S. The use of systems biology in chemical risk assessment. Current Opinion in Toxicology. 2019;

[55] Jager T, Vandenbrouck T, Baas J, De Coen WM, Kooijman SA. A biology-based approach for mixture toxicity of multiple endpoints over the life cycle. Ecotoxicology. 2010;19(2):351-61.

[56] Kumar R, Weigel S, Meyer R, Niemeyer CM, Fuchs H, Hirtz M. Multi-color polymer pen lithography for oligonucleotide arrays. Chemical Communications. 2016;52(83):12310-3.

[57] Lobenhofer EK, Cui X, Bennett L, Cable PL, Merrick BA, Churchill GA, vd. Exploration of lowdose estrogen effects: identification of No Observed Transcriptional Effect Level (NOTEL). Toxicologic pathology. 2004;32(4):482-92.

[58] Fukushima T, Hara-Yamamura H, Nakashima K, Tan LC, Okabe S. Multiple-endpoints gene alteration-based (MEGA) assay: A toxicogenomics approach for water quality assessment of wastewater effluents. Chemosphere. 2017;188:3129.

[59] Poynton HC, Loguinov AV, Varshavsky JR, Chan S, Perkins EJ, Vulpe CD. Gene expression profiling in Daphnia magna part I: concentration-dependent profiles provide support for the no observed transcriptional effect level. Environmental science \& technology. 2008;42(16):6250-6.

[60] Crawford KA, Clark BW, Heiger-Bernays WJ, Karchner SI, Henn BGC, Griffith KN, vd. Altered lipid homeostasis in a PCB-resistant Atlantic killifish (Fundulus heteroclitus) population from New Bedford Harbor, MA, USA. Aquatic toxicology. 2019;210:30-43.

[61] Riley AK, Chernick M, Brown DR, Hinton DE, Di Giulio RT. Hepatic responses of juvenile Fundulus heteroclitus from pollution-adapted and nonadapted populations exposed to Elizabeth River sediment extract. Toxicologic pathology. 2016;44(5):738-48.

[62] Li H, Zhang J, You J. Diagnosis of complex mixture toxicity in sediments: Application of toxicity identification evaluation (TIE) and effectdirected analysis (EDA). Environmental Pollution. 2018;237:944-54.

[63] Arzuaga X, Walker T, Yost E, Radke E, Hotchkiss A. Use of the Adverse Outcome Pathway (AOP) framework to evaluate species concordance and human relevance of Dibutyl Phthalate (DBP)induced male reproductive toxicity. Reproductive Toxicology. 2019;

[64] Liu W, Wu Y, Wang C, Li HC, Wang T, Liao CY, vd. Impact of silver nanoparticles on human cells: effect of particle size. Nanotoxicology. 2010;4(3):319-30.

[65] Krasnov A, Koskinen H, Rexroad C, Afanasyev S, Mölsä H, Oikari A. Transcriptome responses to carbon tetrachloride and pyrene in the kidney and liver of juvenile rainbow trout (Oncorhynchus mykiss). Aquatic Toxicology. 2005;74(1):70-81.

[66] Henry TB, Menn F-M, Fleming JT, Wilgus J, Compton RN, Sayler GS. Attributing effects of aqueous C60 nano-aggregates to tetrahydrofuran decomposition products in larval zebrafish by assessment of gene expression. Environmental Health Perspectives. 2007;115(7):1059-65.

[67] Wagner M, Kienle C, Vermeirssen EL, Oehlmann J. Endocrine disruption and in vitro ecotoxicology: Recent advances and approaches. Içinde: In vitro Environmental Toxicology-Concepts, Application and Assessment. Springer; 2017. s. 1-58.

[68] Roper C, Tanguay RL. Zebrafish as a model for developmental biology and toxicology. Içinde: Handbook of Developmental Neurotoxicology. Elsevier; 2018. s. 143-51.

[69] Bertotto LB, Catron TR, Tal T. Exploring interactions between xenobiotics, microbiota, and neurotoxicity in zebrafish. NeuroToxicology. 2020;76:235-44.

[70] Anbumani S, Kakkar P. Ecotoxicological effects of microplastics on biota: a review. Environmental 
Science and Pollution Research. 2018;25(15):14373-96.

[71] Bada M, Stevens R, Goble C, Gil Y, Ashburner M, Blake JA, vd. A short study on the success of the Gene Ontology. Journal of web semantics. 2004;1(2):235-40.

[72] Gene Ontology Resource [Internet]. Gene Ontology Resource. [a.yer 13 Şubat 2020]. Erişim adresi: http://geneontology.org/

[73] Ebrahimie E, Fruzangohar M, Moussavi Nik SH, Newman M. Gene ontology-based analysis of zebrafish omics data using the web tool comparative gene ontology. Zebrafish. 2017;14(5):492-4.

[74] Ruzicka L, Howe DG, Ramachandran S, Toro S, Van Slyke CE, Bradford YM, vd. The Zebrafish Information Network: new support for non-coding genes, richer Gene Ontology annotations and the Alliance of Genome Resources. Nucleic acids research. 2019;47(D1):D867-73.

[75] Newman M, Hin N, Pederson S, Lardelli M. Brain transcriptome analysis of a familial Alzheimer's disease-like mutation in the zebrafish presenilin 1 gene implies effects on energy production. Molecular brain. 2019;12(1):43.

[76] Howe DG, Bradford YM, Eagle A, Fashena D, Frazer K, Kalita P, vd. The Zebrafish Model Organism Database: new support for human disease models, mutation details, gene expression phenotypes and searching. Nucleic acids research. 2017;45(D1):D758-68.

[77] Larkin P, Villeneuve DL, Knoebl I, Miracle AL, Carter BJ, Liu L, vd. Development and validation of a 2,000-gene microarray for the fathead minnow (Pimephales promelas). Environmental Toxicology and Chemistry: An International Journal. 2007;26(7):1497-506.

[78] KEGG: Kyoto Encyclopedia of Genes and Genomes [Internet]. [a.yer 13 Şubat 2020]. Erişim adresi: https://www.genome.jp/kegg/

[79] GenMAPP - Download Area [Internet]. [a.yer 17 Şubat 2020]. Erişim adresi: http://www.genmapp.org/

[80] Villeneuve DL, Larkin P, Knoebl I, Miracle AL, Kahl MD, Jensen KM, vd. A graphical systems model to facilitate hypothesis-driven ecotoxicogenomics research on the teleost brainpituitary- gonadal axis. Environmental science \& technology. 2007;41(1):321-30.

[81] Xu Z, Liu J, Wu X, Huang B, Pan X. Nonmonotonic responses to low doses of xenoestrogens: a review. Environmental research. 2017;155:199-207.

[82] Liu Z, Huang R, Roberts R, Tong W. Toxicogenomics: A 2020 Vision. Trends in pharmacological sciences. 2019;40(2):92-103.

[83] Vahle JL, Anderson U, Blomme EA, Hoflack J-C, Stiehl DP. Use of toxicogenomics in drug safety evaluation: Current status and an industry perspective. Regulatory Toxicology and Pharmacology. 2018;96:18-29.

[84] Santos EM, Paull GC, Van Look KJ, Workman VL, Holt WV, Van Aerle R, vd. Gonadal transcriptome responses and physiological consequences of exposure to oestrogen in breeding zebrafish (Danio rerio). Aquatic toxicology. 2007;83(2):134-42.

[85] Wilkinson J. Environmental Epigenetics: The Enviro-genomic Interface. 2018;

[86] Patisaul HB, Fenton SE, Aylor D. Animal models of endocrine disruption. Best Practice \& Research Clinical Endocrinology \& Metabolism. 2018;32(3):283-97.

[87] Fedorenkova A, Vonk JA, Lenders HR, Ouborg NJ, Breure AM, Hendriks AJ. Ecotoxicogenomics: Bridging the gap between genes and populations. Environmental science \& technology. 2010;44(11):4328-33.

[88] Amiard-Triquet C. How to improve toxicity assessment? From single-species tests to mesocosms and field studies. Içinde: Aquatic Ecotoxicology. Elsevier; 2015. s. 127-51.

[89] Wang Y, Na G, Zong H, Ma X, Yang X, Mu J, vd. Applying adverse outcome pathways and species sensitivity-weighted distribution to predicted-noeffect concentration derivation and quantitative ecological risk assessment for bisphenol $\mathrm{A}$ and 4nonylphenol in aquatic environments: A case study on Tianjin City, China. Environmental toxicology and chemistry. 2018;37(2):551-62.

[90] Scognamiglio V, Antonacci A, Patrolecco L, Lambreva MD, Litescu SC, Ghuge SA, vd. Analytical tools monitoring endocrine disrupting chemicals. TrAC Trends in Analytical Chemistry. 2016;80:555-67.

[91] McMullen PD, Pendse S, Adeleye Y, Carmichael PL, Andersen ME, Clewell RA. Using Transcriptomics to Evaluate Thresholds in Genotoxicity Dose-Response. Içinde: Toxicogenomics in Predictive Carcinogenicity. Royal Society of Chemistry; 2016. s. 185-208.

[92] Haggard D. Classifying Chemical Bioactivity by Coupling High-throughput Phenotypic Anchoring and Transcriptome Profiling in Zebrafish. 2016;

[93] Mahaye N, Thwala M, Cowan DA, Musee N. Genotoxicity of metal based engineered nanoparticles in aquatic organisms: A review. Mutation Research/Reviews in Mutation Research. 2017;773:134-60.

[94] Kuhn RM, Karolchik D, Zweig AS, Wang T, Smith $\mathrm{KE}$, Rosenbloom KR, vd. The UCSC genome browser database: update 2009. Nucleic acids research. 2009;37(suppl_1):D755-61.

[95] Grondin CJ, Davis AP, Wiegers TC, Wiegers JA, Mattingly CJ. Accessing an expanded exposure science module at the Comparative Toxicogenomics Database. Environmental health perspectives. 2018;126(1):014501.

[96] Saito F. Mechanism-Based Evaluation System for Hepato-and Nephrotoxicity or Carcinogenicity Using Omics Technology. Içinde: Alternatives to Animal Testing. Springer; 2019. s. 91-104.

[97] Baker TK, Engle SK, Halstead BW, Paisley BM, Searfoss GH, Willy JA. Discover Toxicology: An Early Safety Assessment Approach. Içinde: 
Translating Molecules into Medicines. Springer; 2017. s. 119-62.

[98] Wu J-Q, Zhang S-S, Gao H, Qi Z, Zhou C-J, Ji W$\mathrm{W}$, vd. Experimental and theoretical studies on rhodium-catalyzed coupling of benzamides with 2 , 2-difluorovinyl tosylate: diverse synthesis of fluorinated heterocycles. Journal of the American Chemical Society. 2017;139(9):3537-45.

[99] Taboureau O, Audouze K, Brunak S. 3 REACH and Environmental. Computational Methods for Reproductive and Developmental Toxicology. 2015;23.

[100] Broeckaert F, Rossi LH. Regulatory needs for the assessment of respiratory sensitisation under REACH and CLP. Toxicology Letters. 2017; 280:S60.

[101] Maggi L, Zalacain A, Mazzoleni V, Alonso GL, Salinas MR. Comparison of stir bar sorptive extraction and solid-phase microextraction to determine halophenols and haloanisoles by gas chromatography-ion trap tandem mass spectrometry. Talanta. 2008;75(3):753-9.

[102] Shamim N, Gupta A, Paul V, Vida E. Nutritional genomics: A review. The Pharma Innovation. 2017;6(4, Part A): 17: 167-191.

[103] Gao Y, Chen J. Informatics for Nutritional Genetics and Genomics. Içinde: Translational Informatics in Smart Healthcare. Springer; 2017. 143-66. 